- Monográfico -

\title{
LA APLICACIÓN DE LAS DISPOSICIONES DEL SEGUNDO PILAR DEL CONVENIO DE AARHUS EN ESPAÑA. LOS AVANCES Y LOS VIEJOS RETOS
}

\section{THE APPLICATION OF THE SECOND PILLAR OF AARHUS CONVENTION IN SPAIN. PROGRESS AND OLD CHALLENGES}

\author{
CARMEN PlaZa MARTín \\ Profesora titular de Derecho Administrativo \\ Universidad de Castilla-La Mancha \\ Instituto de Derecho Europeo e Integración Regional \\ Universidad Complutense de Madrid
}

Carmen.Plaza@uclm.es

Recibido: 22 de mayo de 2018 / Aceptado: 15 de junio de 2018

RESUMEN: El Convenio de Aarhus ha sido descrito como la iniciativa más ambiciosa hasta la fecha para impulsar la democracia ambiental universal. Transcurridos quince años de su ratificación por España, el objeto de este trabajo es poner en perspectiva los avances que ha supuesto en nuestro ordenamiento en materia de participación pública y examinar algunos de los retos que su aplicación sigue planteando a día de hoy. A tal fin se examinan su ejecución normativa y algunas resoluciones especialmente relevantes en su aplicación judicial, así como los informes de cumplimiento presentados hasta la fecha por el Estado español a las reuniones de las partes del Convenio y las resoluciones adoptadas por el Comité de Cumplimiento del Convenio en relación con España. A la vista de este análisis, se puede concluir que, si bien el ordenamiento español ha experimentado importantes mejoras en la regulación de la participación pública en materia de medio ambiente, todavía se está lejos de alcanzar el objetivo de una participación real y efectiva de la sociedad en la definición y gestión de los intereses generales que afectan a nuestro modelo de desarrollo, por lo que es preciso redoblar los esfuerzos a tal fin.

RESUM: El Conveni d'Aarhus s'ha descrit com la iniciativa més ambiciosa fins avui per impulsar la democràcia ambiental universal. Transcorreguts quinze anys de la ratificació d'Espanya, l'objecte d'aquest treball és posar en perspectiva els avanços que ha suposat en el nostre 
ordenament en matèria de participació pública $\mathrm{i}$, examinar alguns dels reptes que continua plantejant avui dia la seva aplicació. Amb aquesta finalitat cal examinar-ne l'execució normativa i algunes resolucions judicials especialment rellevants en l'aplicació, així com els informes de compliment presentats fins avui per l'Estat espanyol a les reunions de les parts i les resolucions adoptades pel Comitè de Compliment del Conveni en relació amb Espanya. A la vista d'aquesta anàlisi, es pot observar que, si bé l'ordenament espanyol ha millorat la regulació de la participació pública en medi ambient, això no garanteix per se l'objectiu últim d'una implicació i participació activa més grans de la societat en la definició i gestió dels interessos generals que afecten el nostre model de desenvolupament.

ABSTRACT: The Aarhus Convention has been described as the most ambitious initiative of global environmental democracy ever. Fifteen years after Spain ratified the Convention this paper reviews its application and examines some of the challenges confronting its successful implementation. To this end, the paper studies the legislative measures adopted to implement the Convention; some of the most relevant judicial decisions in this matter, as well as the implementation reports submitted by Spain to the Meeting of the Parties to the Convention and the reports adopted by the Aarhus Compliance Committee dealing with Spanish infringements. The Spanish legal order has experienced a significant improvement concerning the regulatory framework for participation in environmental decision-making. However, the aim of achieving a real and effective participation by civil society in the definition and management of those general interests that affect our model of development has not been achieved yet. Therefore, further efforts should be made towards this end.

PALABRAS CLAVES: Convenio de Aarhus - Participación pública - Directivas comunitarias Evaluación ambiental - Autorización integrada - Planes y programas ambientales - Comité de Cumplimiento.

PARAULES CLAU: Conveni d'Aarhus - Participació pública -Directives comunitàries Avaluació ambiental - Autorització integrada - Planes i programes ambientals -Comitè de Compliment.

KEY WORDS: Aarhus Convention - Public participation - EU Directives -Environmental assessment - Integrated pollution permits - Environmental plans and programs - Compliance Committee. 
SUMARIO: I. Introducción. II. Algunas cuestiones generales sobre el segundo pilar del Convenio de Aarhus, el derecho de la Unión y su aplicación en España. 1. Las disposiciones sobre participación en el Convenio de Aarhus. 1.1. Los ámbitos de participación. 1.2. Algunas cuestiones sobre su aplicación. 2. La intermediación del derecho de la Unión. 3. Su articulación en el ordenamiento español: la regulación multinivel del derecho de participación. III. La ejecución normativa en España. 1. El marco general y el alcance específico del derecho de participación en materia de medio ambiente conforme a la Ley 27/2006, de 18 de julio, por la que se regulan los derechos de acceso a la información, de participación pública y de acceso a la justicia en materia de medio ambiente. 2. La participación pública en las decisiones sobre las actividades específicas recogidas en el anexo I del Convenio. 2.1. Participación en la evaluación ambiental de proyectos. i. La participación en la evaluación de impacto ambiental ordinaria de proyectos sujetos a autorización. ii. Otros supuestos de evaluación ambiental de proyectos. iii. Los supuestos excluidos de evaluación ambiental: en particular, la aprobación de proyectos por Ley. 2.2. Participación en las autorizaciones integradas. 3. La participación en la adopción de planes y programas. 3.1. La participación en la adopción de planes y programas sujetos a evaluación estratégica. 3.2. La participación en el segundo ciclo de planificación hidrológica. 4. La participación en la elaboración de disposiciones generales. 4.1. La participación funcional. 4.2. La participación orgánica. IV. Algunas cuestiones sobre el control de su aplicación. 1. Avances en el control judicial del derecho a la "participación efectiva" en materia de medio ambiente. 2. Los mecanismos de control del Convenio. 2.1. Los informes de seguimiento: los avances y obstáculos de los que dan cuenta. 2.2. España ante el Comité de Cumplimiento del Convenio de Aarhus. i. Las comunicaciones ACCC/C/2008/24 y $\mathrm{ACCC} / \mathrm{C} / 2009 / 36$ y la obligación de establecer "plazos razonables" de participación. ii. La Comunicación ACCC/C/2014/99, de 20 de enero 2014, y las "limitaciones" de las comunicaciones a través de las nuevas tecnologías. iii. Comunicación ACCC/C/2014/122, de 12 de diciembre 2014: ¿una "vulneración masiva" de la normativa IPPC? V. Consideraciones finales. VI. Bibliografía.

\section{INTRODUCCIÓN}

Ha transcurrido casi década y media desde que, el 29 de diciembre de 2004, España ratificó el Convenio sobre el acceso a la información, la participación del público en la toma de decisiones y el acceso a la justicia en materia de medio ambiente. Un tiempo que permite poner en perspectiva las medidas adoptadas para aplicar este instrumento internacional, hecho en Aarhus el 25 de junio de 1998, que refuerza la protección del medio ambiente a través de la articulación de derechos subjetivos y colectivos en aras de una implicación más activa de la sociedad en su tutela. Un convenio dirigido a hacer partícipe "a cada persona", y a las organizaciones no gubernamentales en las que estas pueden integrarse, de las decisiones de los poderes públicos que afectan al medio ambiente y que configuran el modelo de desarrollo de nuestra sociedad. 
Descrito como la iniciativa más ambiciosa adoptada hasta la fecha para impulsar la democracia ambiental universal ${ }^{1}$, el Convenio contiene, en su segundo pilar, disposiciones dirigidas a hacer efectivo el Principio 10 de la Declaración de Río sobre el Medio Ambiente y el Desarrollo, según el cual: "El mejor modo de tratar las cuestiones ambientales es con la participación de todos los ciudadanos interesados, en el nivel que corresponda". No existe en este tratado internacional definición alguna de qué ha de entenderse por "participación pública", pero parte de la premisa del importante papel que desempeña la implicación de toda la sociedad en la protección del medio ambiente, como pone de relieve en su preámbulo, para mejorar la calidad y la aplicación eficaz de las medidas adoptadas por las autoridades públicas, garantizar la transparencia y el control de los procesos de toma de decisión, y reforzar el apoyo social de las decisiones así adoptadas $^{2}$. Porque, como puso de relieve Fernández Rodríguez tiempo antes de que comenzase a forjarse este instrumento internacional, sin la participación de los ciudadanos, "cualquier política ambiental [...] por bien construida que esté técnicamente, terminará fracasando por falta de legitimidad"3.

La implicación de la UE en la articulación y negociación del Convenio de Aarhus, primero, y en su posterior ratificación ${ }^{4}$ abrió también una nueva etapa en lo que se refiere a las disposiciones sobre participación pública en el derecho de la Unión Europea y, por lo tanto, en los derechos nacionales. Se adopta así la Directiva 2003/35/CE del Parlamento Europeo y del Consejo, de 26 de mayo de 2003, por la que se establecen medidas para la participación del público en la elaboración de determinados planes y programas relacionados con el medio ambiente y por la que se modifican, en lo que se refiere a la participación del público y el acceso a la justicia, las Directivas 85/337/CEE y 96/61/CE del Consejo (en adelante, Directiva 2003/35/CE para la participación del público), con el objeto de contribuir a la aplicación en los Estados de la Unión de las obligaciones resultantes del Convenio de Aarhus. Una directiva que va a complementar

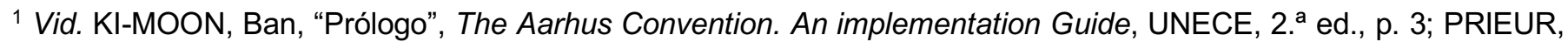
M., "La participation d'Aarhus, instrument universel de la démocratie environnementale", Revue Juridique de l'Environnement, número especial, 9, 1999.

2 Vid. párr. 9. ${ }^{\circ}$ del preámbulo del Convenio, así como UNECE, Maastricht Recommendations on Promoting Effective Public Participation in Decision-making in Environmental Matters (ECE/MP.PP/2014/2/Add.2), p. 6, < https://www.unece.org/environmental-policy/conventions/public-participation/aarhusconvention/tfwg/envppppdm/ppdm-recs.html> [última consulta, 28 de abril de 2018].

${ }^{3}$ FERNÁNDEZ RODRÍGUEZ, T. R., "Derecho, Medio Ambiente, y Desarrollo", REDA, núm. 24, 1980, p. 15. Vid. también las tempranas y relevantes aportaciones de ALONSO GARCÍA, E., "La participación de individuos en la toma de decisiones relativas al medio ambiente en España", Revista española de derecho administrativo, núm. 61, 1989, pp. 49-66; y JORDANO FRAGA, J., "Derecho a la participación, participación administrativa y medio ambiente", Revista Andaluza de Administración Pública, núm. 11, 1992, pp. 99-110.

${ }^{4}$ Decisión 2005/370/CE del Consejo, de 17 de febrero de 2005, sobre la celebración, en nombre de la Comunidad Europea, del Convenio sobre el acceso a la información, la participación del público en la toma de decisiones y el acceso a la justicia en materia de medio ambiente.
} 
las disposiciones específicas sobre participación pública que ya se contenían en otras anteriores, como la Directiva 2001/42/CE del Parlamento Europeo y del Consejo, de 27 de junio de 2001, relativa a la evaluación de los efectos de determinados planes y programas en el medio ambiente (en adelante, Directiva de Evaluación Estratégica), o la Directiva 2000/60/CE del Parlamento Europeo y del Consejo, de 23 de octubre de 2000, por la que se establece un marco comunitario de actuación en el ámbito de la política de aguas (en adelante, Directiva Marco del Agua $)^{5}$.

El Convenio de Aarhus, y las directivas adoptadas por la UE en su marco, impulsaron la adopción de nuestra Ley 27/2006, de 18 de julio, por la que se regulan los derechos de acceso a la información, de participación pública y de acceso a la justicia en materia de medio ambiente, que adecúa la legislación básica en este ámbito a las obligaciones asumidas por España al ratificar el Convenio. Una ley que, como se declara en su exposición de motivos, tiene por objeto articular "los medios instrumentales adecuados" para que los ciudadanos, individual y colectivamente, puedan participar efectivamente en la adopción de medidas dirigidas a garantizar lo dispuesto en el artículo 45 de nuestra Constitución: el derecho de todos a disfrutar de un medio ambiente adecuado para el desarrollo de la persona, así como el deber de conservarlo, mediante la colaboración activa de la sociedad en el cumplimiento del mandato dirigido a los poderes públicos de defender y restaurar el medio ambiente, apoyándose en la indispensable solidaridad colectiva. Participación que nuestra Constitución consagra con carácter general en el artículo 9.2, y en el artículo 105 para el ámbito administrativo en particular, como cauce para una mayor transparencia y acierto en la gestión de los asuntos públicos y para el funcionamiento democrático de la sociedad ${ }^{6}$.

Desde la ratificación del Convenio de Aarhus, una atenta doctrina ha analizado en profundidad sus implicaciones en la regulación de la participación pública en materia de medio ambiente en nuestro ordenamiento, a cuyas obras es obligado remitirse aquí ${ }^{7}$.

\footnotetext{
${ }^{5}$ Vid. al respecto, PLAZA MARTíN, C., Derecho Ambiental de la Unión Europea, Tirant lo Blanch, 2005, p. 573 y ss.

${ }^{6}$ Para un análisis de las bases constitucionales de la Ley, vid. JARIA I MANZANO, J., "El fundamento constitucional de los derechos de participación en materia de medio ambiente y su desarrollo en la ley 27/2006", Pigrau i Solé, A., Acceso a la información, participación pública y acceso a la justicia en materia de medio ambiente: diez años del convenio de Aarhus, Atelier, Barcelona, 2008, pp. 119-148.

7 Vid., sin ánimo de exhaustividad, BERMEJO LATRE, J. L., "La participación del público en la protección de la biodiversidad", Monografías de la Revista Aragonesa de Administración Pública, 2016, pp. 151-176; CUBERO MARCOS, J. L., ITURRIBARRIA RUIZ, M. y LASAGABASTER HERRARTE, I., Acceso a la información, participación y acceso a la justicia en materia de medio ambiente, Gobierno Vasco, 2009; GARCÍA URETA, A., "Algunas cuestiones sobre la regulación del derecho de participación a la luz del Convenio de Aarhus de 1998", Revista Aranzadi de Derecho Ambiental, 7/2005, pp. 43-70; JARIA I MANZANO, J., "La participación del público en la evaluación ambiental estratégica", Revista Aranzadi de Derecho Ambiental, núm. 11, 2007, 213-222;
} 
En este marco, el objeto de este trabajo es exponer los avances que, en ejecución del segundo pilar del Convenio de Aarhus, ha experimentado el derecho español, prestando especial atención a las novedades que se han producido en los últimos años y a algunos de los problemas y retos que se plantean aún hoy para alcanzar una "participación pública efectiva". Retos que, en gran medida, siguen siendo los de siempre. Para ello, se examinará, por una parte, la ejecución normativa del segundo pilar del Convenio a través de las disposiciones de la Ley 27/2006, así como algunas resoluciones judiciales especialmente relevantes en su aplicación. Se dará cuenta, por otra, de las dificultades que señalan los informes de cumplimiento presentados hasta la fecha por el Estado español a las reuniones de las partes del Convenio, así como de las resoluciones adoptadas por el Comité de Cumplimiento en relación con España.

\section{ALGUNAS CUESTIONES GENERALES SOBRE EL SEGUNDO PILAR DEL CONVENIO DE AARHUS, EL DERECHO DE LA UNIÓN Y SU APLICACIÓN EN ESPAÑA}

Antes de abordar cualquier cuestión sobre la aplicación de las disposiciones del segundo pilar del Convenio de Aarhus en España, es preciso recordar sintéticamente las obligaciones que impone a las partes en materia de participación, el papel que juega el derecho de la Unión (no solo mediante la adopción de la Directiva 2003/35/UE para la participación del público) y algunas cuestiones generales sobre cómo se articula su ejecución en nuestro ordenamiento, configurándose un entramado normativo multinivel con un total de cinco esferas regulatorias: internacional, Unión Europea, estatal, autonómica y local.

\footnotetext{
LASAGABASTER HERRARTE, I., "Participación y protección del medio ambiente", García Ureta, A. (coord.), Estudios de Derecho ambiental europeo, Lete, Bilbao, 2005, pp. 13-44; LOZANO CUTANDA, B., "Análisis general de la Ley 27/2006 de acceso a la información, participación pública y acceso a la justicia en materia de medio ambiente", Lozano Cutanda, B. (dir.), Examen de la nueva Ley de acceso a la información, participación pública y acceso a la justicia en materia de medioambiente, Estudios de Derecho Judicial, núm. 137, 2007, pp. 169-206; NOGUEIRA LÓPEZ, A., "La participación en la evaluación de impacto ambiental. Dogma y realidad", García Ureta, A. (coord.), La Directiva de la Unión Europea de evaluación de impacto ambiental de proyectos: balance de treinta años, Marcial Pons, Madrid, 2016, pp. 117-156; de la misma autora, "¿Participación efectiva o quimera procedimental?”, Nogueira López, A. (dir.), Evaluación de impacto ambiental: evolución normativo-jurisprudencial, cuestiones procedimentales y aplicación sectorial, Atelier, Barcelona, pp. 121-145; PALLARÉS SERRANO, A., "La participación pública en materia de medio ambiente", Pigrau i Solé, A., Acceso a la información, participación pública y acceso a la justicia en materia de medio ambiente: diez años del convenio de Aarhus, Atelier, Barcelona, 2008, pp. 299-348; RAZQUIN LIZARRAGA, J. A. y RUIZ DE APODACA ESPINOSA, A., Información, participación y justicia en materia de medio ambiente. Comentario sistemático a la Ley 27/2006, de 18 de julio, ThomsonAranzadi, Cizur Menor, 2007, pp. 279-355.
} 


\section{Las disposiciones sobre participación en el Convenio de Aarhus}

\subsection{Los ámbitos de participación}

El segundo pilar del Convenio de Aarhus, sobre participación del público en materia de medio ambiente, lo integran los artículos 6 a 8 . En ellos se regulan por este orden, y con un grado de densidad y de exigencia decrecientes: (i) la participación en la adopción de decisiones relacionadas con determinadas actividades públicas o privadas; (ii) la participación en los planes, programas y políticas relativos al medio ambiente; y (iii) la participación en la elaboración de disposiciones reglamentarias o de instrumentos normativos jurídicamente obligatorios de aplicación general ${ }^{8}$.

(i) El artículo 6 establece obligaciones especialmente precisas en relación con la "Participación del público en las decisiones relativas a actividades específicas". Dichas actividades son, como dispone su apartado 1.a), las enumeradas en el anexo $\mathrm{I}^{9}$, así como otras actividades de actores públicos o privados que "puedan tener un efecto importante sobre el medio ambiente" (apartado 1.b). Prevé, por otro lado, la posibilidad de que las partes puedan decidir, caso por caso, excepcionar de la aplicación de este artículo aquellas actividades que respondan a necesidades de defensa nacional cuando el derecho interno así lo prevea y se considere que la participación iría contra las exigencias de dicha defensa (apartado 1.c). En relación con las condiciones y los resultados de la participación, cabe destacar, de forma sucinta, que dicho artículo impone las siguientes obligaciones a las autoridades públicas: la de facilitar información "temprana y eficaz" del inicio de un proceso de toma de decisión al "público interesado" (apartado 2); el establecimiento de "plazos razonables" para la participación del "público" en general (apartado

\footnotetext{
${ }^{8}$ Para un examen exhaustivo de las disposiciones del segundo pilar del Convenio de Aarhus, vid. UNECE, The Aarhus Convention, An Implementation Guide, 2. ${ }^{a}$ ed., 2014. Para un análisis doctrinal, vid., GARCÍA URETA, "Algunas cuestiones..." cit., nota 7; PALLARÉS SERRANO, "La participación pública..." cit., p. 301; RAZQUIN LIZARRAGA y RUIZ DE APODACA ESPINOSA, Información, participación... cit., p. 296 y ss.

${ }_{9}$ Vid. el artículo 6.1.a) en relación con el anexo I del Convenio, en el que se enumeran dichas actividades y se precisan las características que han de reunir a tales efectos. Baste aquí con señalar, a modo de ejemplo y sin ánimo de exhaustividad, que entre estas actividades figuran las siguientes: refinerías de petróleo y gas o las centrales nucleares; instalaciones para la producción de hierro fundido o acero; instalaciones destinadas a la producción de cemento, amianto, vidrio o productos cerámicos; instalaciones químicas; instalaciones para la gestión de residuos; determinadas vías para el tráfico ferroviario o por carretera, vías navegables y puertos; ciertos dispositivos de captación o recarga artificial de aguas subterráneas, obras de trasvase de recursos hidráulicos entre cuencas fluviales, y determinadas presas; extracción y canalización de petróleo y gas; instalaciones destinadas a la cría intensiva de determinados animales; mataderos, instalaciones de tratamiento de pieles, tratamiento y transformación de productos alimentarios; y canteras y explotaciones mineras a cielo abierto que rebasen ciertas dimensiones, entre otras. Establece, asimismo, una cláusula general para incluir también a toda "actividad no mencionada en los apartados 1 a 19 supra cuando esté prevista la participación del público respecto de ella en el marco de un procedimiento de evaluación del impacto sobre el medio ambiente conforme a la legislación nacional".
} 
3) y "cuando todas las opciones y soluciones sean aún posibles" (apartado 4); "alentar" a quien tenga propósito de presentar una solicitud de autorización a identificar y a informar sobre esta al "público interesado" (apartado 5); facilitar al "público interesado" el "acceso a todas las informaciones de interés para la toma de decisiones" (apartado 6); prever la posibilidad de que el "público en general" presente alegaciones por escrito o, en audiencia o investigación pública, todas las observaciones que estime pertinentes (apartado 7); tener "debidamente en cuenta" los resultados de la consulta (apartado 8); e informar rápidamente al "público en general" una vez adoptada la decisión, comunicándola con los motivos y las consideraciones en los que se base (apartado 9). Obligaciones todas estas que también se aplican, mutatis mutandis, a la revisión o actualización de las condiciones en que se ejercen las actividades del anexo I (apartado 10). Finalmente, el apartado 11 del artículo 6 deja a la discrecionalidad de las partes la aplicación del resto de los apartados a las decisiones sobre la autorización para la diseminación en el medio ambiente de organismos genéticamente modificados ${ }^{10}$.

(ii) El artículo 7 regula la "Participación del público en los planes, programas y políticas relativos al medio ambiente" de forma mucho menos precisa, permitiendo un amplio margen de discrecionalidad a las partes. El Convenio no define qué ha de entenderse por "planes y programas relacionados con el medio ambiente" y utiliza esos conceptos en un sentido amplio, de forma que pueden comprender estrategias medioambientales generales que encuadren planes, programas o medidas concretas. Obliga a cada parte a adoptar las "disposiciones prácticas u otras disposiciones necesarias" para que el público pueda participar durante la preparación de planes y programas relacionados con el medio ambiente en un "marco transparente y equitativo" tras haberle proporcionado previamente la información necesaria a tales efectos. Precisa, sin embargo, que en la elaboración de dichos planes y programas se aplicarán los apartados 3,4 y 8 del artículo 6 (de manera que todos los procedimientos deberán establecer plazos razonables para las diferentes fases de participación, quese garantizará dicha participación cuando las distintas opciones posibles estén abiertas, y que su resultado deberá ser tomado en la debida consideración por las autoridades públicas). La designación de qué público podrá participar se deja en manos de la autoridad pública competente. Por lo que se refiere a la elaboración y preparación de políticas ambientales, el artículo 7 in fine se limita solamente a establecer una mera recomendación carente de fuerza vinculante: cada parte

\footnotetext{
${ }^{10}$ Si bien por Decisión II/1 de las Partes de 2005 se acordó una modificación al Convenio para introducir un nuevo artículo 6bis, acompañado de un anexo con disposiciones específicas para la participación pública en este ámbito, a fecha de hoy todavía no ha entrado en vigor al no haber recibido aún todas las ratificaciones necesarias.
} 
"deberá esforzarse por establecer oportunidades para que el público participe en la preparación de las políticas ambientales".

(iii) Finalmente, el artículo 8 regula la "Participación del público durante la fase de elaboración de disposiciones reglamentarias o de instrumentos normativos jurídicamente obligatorios de aplicación general". Se limita a disponer, de forma incluso más laxa, que cada parte en el Convenio "se esforzará en promover" una participación pública efectiva durante la preparación por las autoridades públicas de reglamentos ejecutivos o de otras disposiciones de carácter general que puedan tener un efecto significativo en el medio ambiente, durante el estadio apropiado y mientras las opciones están aún abiertas. Con este objeto, el Convenio menciona, a título meramente indicativo, algunas de las medidas idóneas a dicho fin (como la fijación de plazos suficientes para una efectiva participación pública; la publicación o puesta a disposición del público de los borradores de propuestas; o "dar al público la oportunidad de formular observaciones", directamente o a través de órganos consultivos representativos). El artículo 8 termina encomendando a las partes del Convenio que tengan en consideración los resultados de la participación del público "en todo lo posible".

\subsection{Algunas cuestiones sobre su aplicación}

Tal y como se ha expuesto, estas disposiciones imponen obligaciones en unos casos y meras recomendaciones en otros, dirigidas a posibilitar o impulsar una participación "efectiva" del público en distintos momentos o fases de los procedimientos a través de los que se adoptan las decisiones, los planes y los programas, o disposiciones de carácter general en materia de medio ambiente.

En su seno se distinguen dos posibles círculos de participación: el del "público" (en general, sin limitaciones) ${ }^{11}$; y el del "público interesado" (por estar directamente afectado o ser titular de intereses específicos) $)^{12}$, al que las disposiciones del Convenio garantizan una participación más intensa desde el comienzo mismo del procedimiento. Si bien compete a las autoridades públicas de cada Estado identificar para cada caso quién puede ser el "público interesado", el Convenio precisa que tendrán esta condición las ONG que trabajan en defensa del medio ambiente, a las

\footnotetext{
${ }^{11}$ Definido en el artículo 2.4 como "una o varias personas físicas o jurídicas y, con arreglo a la legislación o la costumbre del país, las asociaciones, organizaciones o grupos constituidos por dichas personas".

12 Definido en el artículo 2.5 del Convenio como "el público que resulta o puede resultar afectado por las decisiones adoptadas en materia medioambiental o que tiene un interés que invocar en la toma de decisiones", entendiendo que "tienen tal interés las organizaciones no gubernamentales que trabajan en favor de la protección del medioambiente y que cumplen los requisitos exigidos por el derecho interno".
} 
que se garantiza el derecho a participar en todo momento conforme a los "requisitos exigidos por el derecho interno", reconociéndoles así un importante papel en la defensa del medio ambiente.

La "participación efectiva" que persigue el Convenio depende necesariamente de la debida aplicación de sus otros dos pilares: el del acceso a la información, para posibilitar una participación con el necesario conocimiento, y el del acceso a la justicia, para remediar las posibles vulneraciones de dichos derechos ${ }^{13}$. Para ello, los Estados deben adoptar cuantas medidas legales, reglamentarias o de otro tipo sean necesarias, así como las medidas de ejecución apropiadas ${ }^{14}$.

A la hora de aplicar sus disposiciones se deben tener en cuenta, además, los mecanismos de cumplimiento adoptados por las partes conforme al artículo 15. En particular, los pronunciamientos que sobre las disposiciones del Convenio emanan de sus órganos, como la reunión de las partes o el Comité de Cumplimiento, a los que haremos referencia más adelante $^{15}$. Cabe adelantar en este punto que dicho Comité, mediante los informes que elabora a raíz de las comunicaciones que recibe del público con denuncias sobre situaciones de incumplimiento en los Estados parte, clarifica y precisa el alcance de las disposiciones del Convenio que, cuajadas de conceptos jurídicos indeterminados, dejan amplios márgenes de discrecionalidad en su ejecución a las autoridades nacionales. En la elaboración de dichos informes, el Comité también toma en consideración instrumentos tales como las recomendaciones y guías elaboradas por los grupos de trabajo creados por la Conferencia de las Partes. Se produce así una intensa interrelación entre las disposiciones del Convenio e instrumentos de soft law gestados en el seno de las instituciones u órganos creados bajo el auspicio del Convenio. El más relevante en relación con el segundo pilar del Convenio son las "Recomendaciones de Maastricht para promover la efectiva participación pública en las decisiones sobre medio ambiente"16, adoptadas en 2015 por el Grupo de Trabajo sobre Participación Pública en la Toma de Decisiones (TFPPD) a instancia de la reunión de las partes. Las Recomendaciones de Maastricht se conciben como una herramienta de orientación y asistencia a las autoridades públicas, de carácter no vinculante, para mejorar la implementación

\footnotetext{
${ }^{13}$ Para una visión general del Convenio y su desarrollo ulterior, vid. PIGRAU SOLÉ, A. y BORRÁS PENTINAT, S., "Diez años del Convenio de Aahrus sobre el acceso a la información, la participación y el acceso a la justicia en materia de medio ambiente", Pigrau Solé (dir.), Acceso a la información... cit., pp. 21-80.

14 Art. 3 del Convenio.

${ }^{15}$ Vid. apartado IV.2 infra.

16 Vid. Maastricht Recommendations on Promoting Effective Public Participation in Decision-making in Environmental Matters, Report of the fifth session of the Meeting of the Parties, Addendum, 29 de enero de 2015, ECE/MP.PP/2014/2/Add. 2.
} 
de las disposiciones del Convenio sobre participación pública. No obstante, el Comité de Cumplimiento se ha apoyado para precisar en casos concretos el alcance de algunos de los conceptos utilizados en los artículos 6,7 y 8 del Convenio ${ }^{17}$.

Por otro lado, al haber sido ratificado el Convenio por la Unión Europea, sus disposiciones también están siendo objeto de interpretación judicial, de forma uniforme para todos los Estados miembros, por parte del Tribunal de Justicia de la Unión Europea, tal y como se examina a continuación.

\section{La intermediación del derecho de la Unión}

La Decisión 2005/370 del Consejo, de 17 de febrero de 2005, sobre la celebración, en nombre de la Comunidad Europea, del Convenio sobre el acceso a la información, la participación del público en la toma de decisiones y el acceso a la justicia en materia de medio ambiente, supuso la integración del Convenio en el derecho de la Unión.

Este instrumento internacional, en cuya negociación participaron activamente la Unión y sus Estados miembros, se inspiró en gran medida en la legislación comunitaria existente en materia de acceso a la información y participación pública hasta la fecha. En las disposiciones sobre participación se tuvo en consideración, en particular, lo establecido en la Directiva 85/337/CEE del Consejo, de 27 de junio de 1985, relativa a la evaluación de las repercusiones de determinados proyectos públicos y privados sobre el medio ambiente (en adelante, Directiva EIA), y en la Directiva 96/61/CE del Consejo, de 24 de septiembre de 1996, relativa a la prevención y al control integrados de la contaminación (en adelante, Directiva IPPC), razón por la que la Comisión Europea consideró en un principio que las obligaciones que se asumirían con el Convenio quedarían cubiertas con estas dos directivas ${ }^{18}$. Sin embargo, las exigencias de participación del público y los requisitos mínimos que han de satisfacer las autoridades públicas conforme al artículo 6 del Convenio resultaron ser finalmente más amplios y precisos que los de dichas directivas, lo que motivó que la Comisión pusiera en marcha, antes de la adhesión al Convenio, la revisión de ambas. Era necesario adoptar, asimismo, nuevas disposiciones para cumplir las exigencias de participación del público en la elaboración de planes y programas

\footnotetext{
17 Vid., por ejemplo, Findings and recommendations with regard to communication ACCC/C/2014/99 concerning compliance by Spain, 31 de agosto de 2017, ECE/MP.PP/C.1/2017/17, p. 7, que se analiza en el apartado IV.2.b), p. 51 infra.

${ }^{18}$ Propuesta de la Comisión para una Decisión del Consejo sobre la firma de la Comunidad Europea del Convenio UN/ECE sobre acceso a la información, participación pública y acceso a la justicia en asuntos ambientales, $\operatorname{COM}(1998) 344$ final, p. iii.
} 
establecidas en el artículo 7 del Convenio, razón por la que se aprueba la Directiva 2003/35/CE del Parlamento Europeo y del Consejo, de 26 de mayo de 2003, por la que se establecen medidas para la participación del público en la elaboración de determinados planes y programas relacionados con el medio ambiente y por la que se modifican, en lo que se refiere a la participación del público y el acceso a la justicia, las Directivas 85/337/CEE y 96/61/CE del Consejo. Directiva que va a servir de este modo de marco comunitario para la adecuación del ordenamiento español a determinadas exigencias del Convenio de Aahrus en materia de participación ${ }^{19}$.

La Directiva 2003/35/CE no va a cubrir, sin embargo, todos los tipos de participación que abarca el Convenio: no aborda la participación del público en la elaboración de políticas ambientales (que, como hemos visto, se formula en el Convenio como una mera recomendación) ni tampoco en la elaboración de normas reglamentarias relacionadas con el medio ambiente, cuestión esta que se deja a la entera autonomía institucional y procedimental de los Estados miembros ${ }^{20}$. Finalmente, y por lo que se refiere a la participación del público en decisiones relativas a la diseminación voluntaria en el medio ambiente o la comercialización de organismos modificados genéticamente (OMG), por Decisión 2006/975/CE, de 18 de diciembre de 2006, el Consejo UE aprobó en nombre de la Comunidad la enmienda al Convenio de Aarhus sobre la participación del público en este ámbito (la cual aún no han entrado en vigor al no haber recibido todavía todas las ratificaciones necesarias). La Unión va a considerar que las obligaciones que introduce en el Convenio el nuevo artículo 6 bis y su anexo se cumplen en la Unión a través de la Directiva 2001/18/CE del Parlamento Europeo y del Consejo, de 12 de marzo de 2001, sobre la liberación intencional en el medio ambiente de organismos modificados genéticamente y por la que se deroga la Directiva 90/220/CEE del Consejo, y el Reglamento (CE) n. ${ }^{\circ}$ 1829/2003 del Parlamento Europeo y del Consejo, de 22 de septiembre de 2003, sobre alimentos y piensos modificados genéticamente.

\footnotetext{
${ }^{19}$ Para un análisis y valoración de la aplicación del Convenio de Aarhus por la Unión Europea, vid., en este mismo número, el trabajo de L. KRÄMER.

${ }^{20}$ Para un análisis de las novedades que introdujo esta directiva, vid. GONZÁLEZ BONDÍA, A., "La regulación comunitaria del acceso a la información, la participación pública y el acceso a la justicia en materia de medio ambiente en sus Estados miembros", Pigrau Solé (dir.), Acceso a la información... cit., pp. 97-107.
} 


\section{Su articulación en el ordenamiento español: la regulación multinivel del derecho de participación}

Conforme al artículo $96 \mathrm{CE}$, el Convenio de Aarhus es de aplicación directa en España una vez publicado oficialmente en nuestro país. Por ello, en principio, no sería necesaria la intermediación de derecho interno alguno para su aplicación, salvo, claro está, el desarrollo normativo preciso de aquellas disposiciones que imponen mandatos a los poderes públicos necesitados de concreción por el legislador nacional para garantizar su aplicación. Tal es el caso de aquellas que establecen principios como el de "participación temprana" o el de "participación eficaz" que deben ser aplicados mediante disposiciones internas que precisen los trámites, los plazos y las obligaciones concretas de las Administraciones en los procedimientos a través de los cuales las autoridades públicas competentes adoptan las decisiones, los planes y los programas o normas ambientales objeto del Convenio.

Por otro lado, la intermediación del derecho de la Unión en la aplicación del Convenio va a tener notables repercusiones en relación con su cumplimiento. En primer lugar porque, como es sabido, los Estados miembros están obligados a adecuar de forma puntual y correcta sus ordenamientos nacionales a estas directivas comunitarias (artículo 288 TFUE), operando en caso contario los principios de primacía del derecho de la Unión, de interpretación conforme del derecho nacional con las directivas y, en su caso - si se dan los requisitos necesarios de incondicionalidad y precisión-, el de efecto directo de sus disposiciones o el de responsabilidad del Estado por los daños que pueda ocasionar el incumplimiento de las disposiciones de las directivas que reconocen derechos a los particulares ${ }^{21}$. En segundo lugar, porque su correcta ejecución, tanto formal como práctica $-\mathrm{y}$, por tanto, el cumplimiento de las obligaciones del Convenio de Aarhus a las que responden-, queda sometida a la supervisión de la Comisión Europea y al control último del Tribunal de Justicia de la Unión (TJUE) mediante el recurso de incumplimiento regulado en los artículos 258 a 260 del TFUE ${ }^{22}$. Y, en tercer lugar, pero no menos importante, por el mecanismo de diálogo y cooperación judicial entre los jueces nacionales y el TJUE, que se articula a través de la cuestión prejudicial regulada en el artículo 267 TFUE: a través de las cuestiones sobre la interpretación de la Directiva o del Convenio que plantean los órganos judiciales nacionales, el Tribunal de Justicia de la Unión Europea puede

\footnotetext{
${ }^{21}$ Sobre la aplicación de dichos principios a las directivas de medio ambiente, vid. PLAZA MARTíN, C., Derecho Ambiental de la Unión Europea, p. 1172 y ss.

22 Vid., por ejemplo, las sentencias del TJUE en los asuntos C-427/07, Comisión c. Irlanda, de 16.7.2009, y C530/11, Comisión c. Reino Unido, de 13.2.2014.
} 
garantizar una interpretación uniforme de dichas disposiciones en todos los Estados miembros. De hecho, el Tribunal se ha pronunciado ya en diversas ocasiones sobre la interpretación que debe darse a las disposiciones del Convenio de Aarhus - que forman parte del derecho de la Unión- en conjunción con las de las directivas ambientales, con pronunciamientos que refuerzan la eficacia de dichas disposiciones ${ }^{23}$. Ha abordado, incluso, la naturaleza y el alcance de documentos o guías relacionados con su aplicación y publicados a instancia de los órganos del Convenio ${ }^{24}$.

La inclusión en las directivas comunitarias de disposiciones sobre participación en línea con el Convenio y los mecanismos de control de cumplimiento del derecho de la Unión pueden explicar el hecho, puesto de relieve por el Comité de Cumplimiento del Convenio de Aarhus, de que "la mayoría de los Estados parecen basarse en el Derecho Comunitario cuando redactan su legislación nacional para implementar las obligaciones internacionales que se derivan de un Tratado del que la Comunidad también es parte"25.

Es este el marco internacional y comunitario en el que se adopta la Ley 27/2006, de 18 de julio, por la que se regulan los derechos de acceso a la información, de participación pública y de acceso a la justicia en materia de medio ambiente. La Ley se adoptó con unos meses de retraso con respecto a la fecha límite de transposición de la Directiva 2003/35CE —puesto que tenía que haber sido incorporada al ordenamiento interno antes del 25 de junio de 2005-, lo que dio lugar a la apertura de un procedimiento de infracción por parte de la Comisión Europea contra el Reino de España por "no comunicación", que derivó en la interposición de un recurso por

\footnotetext{
23 Vid., por ejemplo, la STJUE de 8 de noviembre de 2016 (Gran Sala), asunto C-243/15 Asociación para la Protección de los Bosques VLK "LZ", sobre el artículo 6 del Convenio y el derecho de participación que se reconoce a una organización de defensa del medio ambiente en un caso relacionado con el proceso de autorización de un proyecto en un lugar protegido con arreglo al artículo 6, apartado 3, de la Directiva 92/43/CEE del Consejo, de 21 de mayo de 1992, relativa a la conservación de los hábitats naturales y de la fauna y flora silvestres, en la que el Tribunal de Justicia declara que el artículo 6, apartado 1, letra b), del Convenio de Aarhus, "confiere a las organizaciones de defensa del medio ambiente que, como LZ, cumplen los requisitos establecidos en el artículo 2, apartado 5, de ese Convenio, un derecho a participar [...] en el procedimiento de adopción de una decisión relativa a una solicitud de autorización de un plan o de un proyecto que pueda tener un efecto importante sobre el medio ambiente en la medida en que, en el marco de dicho procedimiento, deba adoptarse alguna de las decisiones a las que se refiere el artículo 6, apartado 3, de dicha Directiva", apartado 49.

${ }^{24}$ Vid. As. C-182/2010 Marie-Noëlle Solvay y otros, de 16 de febrero de 2012. En este caso, el órgano nacional preguntó sobre el valor jurídico de la Guía de Aplicación del Convenio (UNECE, The Aarhus Convention... cit.) a la hora de interpretar las disposiciones sobre participación y acceso a la justicia que estaban en cuestión en este caso. EI TJUE declaró al respecto que, "aunque para la interpretación de los artículos 2, apartado 2, y 9, apartado 4, del Convenio de Aarhus se puede tomar en consideración la Guía de aplicación de ese Convenio, dicha Guía no tiene sin embargo ninguna fuerza obligatoria y carece del alcance normativo inherente a las disposiciones del referido Convenio", apartado 28.
}

${ }^{25} \mathrm{ECE}, \mathrm{ACC} / \mathrm{C} / 2006 / 17$. 
incumplimiento ante el Tribunal de Justicia de la Unión Europea ${ }^{26}$, finalmente archivado por desistimiento de la Comisión tras la comunicación a dicha institución, y el examen por esta, de la Ley $27 / 2006^{27}$.

Atendiendo a la distribución constitucional de competencias entre el Estado y las comunidades autónomas, y conforme al artículo 149.1.23 $\mathrm{CE}$, esta ley "se limita a establecer aquellas garantías y principios que deben ser observados por todas las autoridades públicas ante las que pretendan ejercerse los derechos de acceso a la información, participación y acceso a la justicia en materia de medio ambiente, sin entrar a regular el procedimiento para su ejercicio", según declara su exposición de motivos. Su finalidad es, en definitiva, adecuar la normativa básica ambiental a la Directiva comunitaria, articulando así también, a través de normas aplicables a todas las Administraciones, unas garantías mínimas para la aplicación del Convenio en todo el Estado.

Las disposiciones del Convenio y de las directivas y las bases establecidas en la Ley 27/2006 enmarcan el ejercicio de las competencias asumidas por las comunidades autónomas de conformidad con sus estatutos. A estas les corresponde adoptar las medidas necesarias para garantizar la participación efectiva del público en los procedimientos a través de los cuales adopten decisiones, planes o programas, o normas ambientales de su competencia ${ }^{28}$. Pueden, asimismo, establecer medidas adicionales que refuercen los derechos de participación en sus ámbitos de acción en materia de medio ambiente. En definitiva, las comunidades autónomas juegan un papel primordial en la ejecución del Convenio de Aarhus, dado que no solo tienen competencia para desarrollar la legislación básica en materia de medio ambiente y para establecer normas de mayor protección, sino que a ellas corresponde con carácter general la

26 As. C-2016/06, Comisión c. España, por no haber adoptado las disposiciones legales, reglamentarias y administrativas necesarias para cumplir la Directiva 2003/35/CE (vid. DOUE C 165/19, de 15 de julio de 2006).

${ }^{27}$ Auto del Presidente del TJUE de 22 de noviembre de 2006 (vid. DOUE C 331/26, de 30 de diciembre de 2006).

${ }^{28}$ Vid., entre otras, la Ley 7/2007, de 9 de julio, de Gestión Integrada de la Calidad Ambiental, de la Junta de Andalucía, y el Decreto 347/2011, de 22 de noviembre, por el que se regula la estructura y funcionamiento de la Red de Información Ambiental de Andalucía y el acceso a la información ambiental; la Ley 11/2014, de 4 de diciembre, de Prevención y Protección Ambiental de Aragón; la Ley de Canarias 14/2014, de 26 de diciembre, de Armonización y Simplificación en materia de Protección del Territorio y de los Recursos Naturales; la Ley 4/2006, de 19 de mayo, de Conservación de la Naturaleza de Cantabria; la Ley 20/2009, de 4 de diciembre, de prevención y control ambiental de las actividades, de la Generalitat de Cataluña; la Ley 16/2015, de 23 de abril, de protección ambiental de la Comunidad Autónoma de Extremadura; el Decreto 97/2010, de 11 de junio, del Consell, por el que se regula el ejercicio del derecho de acceso a la información ambiental y de participación pública en materia de medio ambiente de la Comunitat Valenciana; la Ley 17/2006, de 11 de diciembre, de Control Ambiental Integrado de Cantabria y su reglamento, aprobado por Decreto 19/2010, de 18 de marzo; la Ley 5/2002, de 8 de octubre, de Protección del Medio Ambiente de La Rioja; la Ley 11/2003, de 8 de abril, de Prevención Ambiental de Castilla y León; la Ley 3/1998, de 27 de febrero, General de Protección del Medio Ambiente del País Vasco; la Ley 8/2007, de 15 de marzo, de modificación de la Ley 9/1999, de 26 de mayo, de Conservación de la Naturaleza de Castilla-La Mancha; la Ley 7/2008, de 7 de julio, de protección del paisaje de Galicia; y la Ley 5/2010, de 23 de junio, de Prevención y Calidad Ambiental de la Comunidad Autónoma de Extremadura, entre otras. 
competencia ejecutiva en este ámbito ${ }^{29}$. Igualmente relevante es la aplicación de las disposiciones del Convenio por los entes locales en el ejercicio de las competencias en materia de medio ambiente y urbanismo que tienen atribuidas conforme al artículo 25.2 de la Ley 7/1985, de 2 de abril, reguladora de las Bases del Régimen Local (en adelante, LBRL).

La regulación y aplicación de los procedimientos concretos —que incorporen los trámites y las previsiones necesarios para garantizar la efectiva participación del público- corresponde, en definitiva, a las distintas Administraciones, estatal, autonómica o municipal, con competencias en materia de medio ambiente. Cada una de ellas deberá incorporar, en sus respectivos ámbitos de actividad, las medidas precisas para aplicar tales principios y garantías en cumplimiento de las disposiciones del Convenio y de la Directiva comunitaria —que vinculan a todos los poderes y autoridades del Estado-, así como de las disposiciones básicas establecidas en la Ley 27/2006 y en otras normas básicas a las que esta remite, y que pueden ser, en su caso, exigidas frente a cualquier Administración y, llegado el caso, invocadas ante los tribunales.

Cualquier conflicto de una norma interna con las disposiciones de las directivas $-\mathrm{y}$ del Convenio, por cuanto también forma parte del derecho de la Unión- debe ser resuelto por los tribunales nacionales atendiendo a los principios de primacía, de interpretación conforme del derecho nacional con las directivas y el Convenio, y, en su caso, de efecto directo de las disposiciones del derecho de la Unión en los términos reconocidos por la jurisprudencia del Tribunal de Justicia de la Unión Europea ${ }^{30}$.

Hasta ahora, el Tribunal de Justicia de la Unión Europea se ha pronunciado fundamentalmente sobre la falta de efecto directo de las disposiciones del Convenio sobre acceso a la justicia, declarando que "ni el apartado 3 ni el apartado 4 del artículo 9 del Convenio de Aarhus contienen ninguna obligación incondicional y suficientemente precisa que pueda determinar directamente la situación jurídica de los particulares"31. Sin embargo, pronunciamientos recientes del Tribunal de Justicia de la Unión Europea ponen de relieve, en relación con el derecho de participación reconocido en el artículo 6 del Convenio, que puede ser directamente invocado por los particulares ante las Administraciones y los tribunales; así se infiere de la Sentencia de 20 de diciembre de 2017, as. C-664/15, Protect Natur-, Arten- und Landschaftsschutz Umweltorganisation, para aquellos supuestos en que las autoridades

\footnotetext{
${ }^{29}$ Vid., entre otras muchas, SSTC 102/1995, de 26 de junio, FJ 9. ${ }^{\circ} ; 101 / 2005$, de 20 de abril, FJ 5. o; 141/2016, de 15 de agosto, FJ 6. ${ }^{\circ}$; 53/2017, de 15 de junio, FJ 4. ${ }^{\circ}$.

30 Vid. PLAZA MARTíN, Derecho Ambiental... cit. p. 1172 y ss.

31 Vid. SSTJUE de 8 de marzo de 2011, as. C-240/09, Lesoochranárske zoskupenie, apartados 47, 48, 51 y 52 ; de 20 de diciembre de 2017, as. C-664/15, Protect Natur, apartado 45; y de 15 de marzo de 2018, as. C-470/16, North East Pylon, apartado 53.
} 
públicas adopten decisiones sobre actividades enumeradas en el anexo I del Convenio, así como sobre actividades que, pese a no estar en dicho anexo - como era el caso en este asunto-, tengan un efecto importante sobre el medio ambiente, supuestos en los que "podrá afirmarse que, en virtud del artículo 6 del Convenio de Aarhus Protect Natur [la ONG que lo invocaba] es titular de un derecho de participación en el procedimiento administrativo de autorización"32.

Además, el Tribunal de Justicia de la Unión Europea ha declarado que los tribunales nacionales están obligados a interpretar el derecho procesal nacional de conformidad con las disposiciones del Convenio y de las directivas a él vinculadas y que, cuando dicha interpretación conforme no sea posible, deben inaplicar —en virtud del principio de primacía del derecho de la Unión- las disposiciones nacionales que impiden, de forma contraria al Convenio, el ejercicio de los derechos que reconoce a ciudadanos y ONG. En este sentido, argumenta lo siguiente:

[...] sería incompatible con las exigencias inherentes a la propia naturaleza del Derecho de la Unión toda disposición de un ordenamiento jurídico nacional o toda práctica, legislativa, administrativa o judicial, que redujese la eficacia del Derecho de la Unión al negar al juez competente para aplicarlo la facultad de hacer, en el mismo momento de esa aplicación, todo lo necesario para excluir las disposiciones legislativas nacionales que pudiesen constituir un obstáculo a la plena eficacia de las normas de la Unión (véanse, en particular, las sentencias de 9 de marzo de 1978, Simmenthal,106/77, EU:C:1978:49, apartado 22, y de 5 de abril de 2016, PFE, C-689/13, EU:C:2016:199, apartado 41 y jurisprudencia citada) ${ }^{33}$.

\footnotetext{
32 Apartado 66. En este caso, la Administración austriaca del distrito de Gmünd denegó a la ONG Protect la condición de parte en los procedimientos seguidos con arreglo a la normativa austriaca de aguas sobre la base de que no había invocado la lesión de ningún derecho protegido en virtud de dicha normativa y, en consecuencia, no podía obtener la condición de parte en el procedimiento. Vid. también asunto C-243/15 Asociación para la Protección de los Bosques VLK «LZ» cit., nota 23 supra.

${ }^{33}$ Vid., sintetizando esta doctrina, As. C-664/15, Protect Natur, cit., párr. 57,
} 


\section{LA EJECUCIÓN NORMATIVA EN ESPAÑA}

\section{El marco general y el alcance específico del derecho de participación en materia de} medio ambiente conforme a la Ley 27/2006, de 18 de julio, por la que se regulan los derechos de acceso a la información, de participación pública y de acceso a la justicia en materia de medio ambiente

El legislador ha establecido, en consonancia con los mandatos que estipulan los artículos 9.2 y 105 de la Constitución, unos mecanismos mínimos de "participación" de los ciudadanos en la actividad de las Administraciones, comunes para todas ellas, que en la actualidad se encuentran regulados en la nueva Ley 39/2015, de 1 de octubre, del Procedimiento Administrativo Común de las Administraciones Públicas (LPAC). Dicha Ley recoge trámites con una larga tradición en nuestro ordenamiento, como el de audiencia al interesado (art. 82) o el de información pública, que "podrá acordar el órgano al que corresponda la resolución del procedimiento, cuando la naturaleza de éste lo requiera", a fin de que cualquier persona física o jurídica pueda examinar el expediente, o la parte de este que se acuerde, y formular alegaciones u observaciones a las que la Administración ha de dar una respuesta razonada (art. 83). La Ley define, asimismo, conceptos fundamentales para determinar quién puede participar en todo caso en un procedimiento, como el concepto de “interesado" (art. 4), así como los derechos de las personas en sus relaciones con las Administraciones públicas y que configuran, entre otras cosas, las formas de comunicación con estas (art. 13).

Junto a dichos trámites —existentes en leyes precedentes, como la Ley 30/1992, de 26 de noviembre, de Régimen Jurídico de las Administraciones Públicas y del Procedimiento Administrativo Común, y, antes, la Ley de 17 de julio de 1958, sobre Procedimiento administrativo-, la Ley 39/2015 introduce una importante novedad, ya que en su artículo 133 establece por vez primera, para todas las Administraciones públicas, disposiciones dirigidas a articular la participación de los ciudadanos en el procedimiento de elaboración de normas tanto con rango de ley como reglamentarias - en los términos que se analizarán en un apartado posterior.

Este marco general va a verse superado de forma muy notable en el ámbito del medio ambiente por la Ley 27/2006, de 18 de julio, por la que se regulan los derechos de acceso a la información, de participación pública y de acceso a la justicia en materia de medio ambiente (en 
adelante, Ley 27/2006 IPPAJMA), que establece disposiciones mucho más precisas para garantizar lo que denomina - en aplicación del Convenio de Aarhus - una participación "real y efectiva" en la adopción de las decisiones públicas en esta materia, que se configura como elemento clave y distintivo de este sector. Se pone así de relieve la voluntad de promover una participación activa y útil que permita a la Administración interactuar con la sociedad en la definición del interés general en temas que afectan al medio ambiente, y su plasmación en decisiones concretas, más allá del cumplimiento de meros trámites burocráticos dirigidos a "cubrir el expediente".

Conforme al artículo 3.2 de la Ley 27/2006 IPPAJMA, la participación pública en este ámbito conlleva que toda persona pueda ejercer, en su relación con las autoridades públicas, los siguientes derechos:

a) A participar de manera efectiva y real en la elaboración, modificación y revisión de aquellos planes, programas y disposiciones de carácter general relacionados con el medio ambiente incluidos en el ámbito de aplicación de esta Ley.

b) A acceder con antelación suficiente a la información relevante relativa a los referidos planes, programas y disposiciones de carácter general.

c) A formular alegaciones y observaciones cuando estén aún abiertas todas las opciones y antes de que se adopte la decisión sobre los mencionados planes, programas o disposiciones de carácter general y a que sean tenidas debidamente en cuenta por la Administración Pública correspondiente.

d) A que se haga público el resultado definitivo del procedimiento en el que ha participado y se informe de los motivos y consideraciones en los que se basa la decisión adoptada, incluyendo la información relativa al proceso de participación pública.

e) A participar de manera efectiva y real, de acuerdo con lo dispuesto en la legislación aplicable, en los procedimientos administrativos tramitados para el otorgamiento de las autorizaciones reguladas en la legislación sobre prevención y control integrado de la contaminación, para la concesión de los títulos administrativos regulados en la legislación en materia de organismos modificados genéticamente, y para la emisión de las declaraciones de impacto ambiental reguladas en la legislación sobre evaluación de impacto ambiental, así como en los procesos planificadores previstos en la legislación de aguas y en la legislación sobre evaluación de los efectos de los planes y programas en el medio ambiente.

Siguiendo el mismo esquema, el título III de la Ley aborda la regulación del derecho a la participación en los asuntos de carácter ambiental específicamente en relación con la 
elaboración, revisión o modificación de determinados planes, programas y disposiciones de carácter general (arts. 16 a 18). Dichos artículos establecen las garantías de información y procedimiento básicas que las Administraciones públicas han de salvaguardar para promover una participación "real y efectiva del público". En concreto, el apartado 1 del artículo 16 establece que las Administraciones públicas velarán porque:

a) Se informe al público, mediante avisos públicos u otros medios apropiados, como los electrónicos, cuando se disponga de ellos, sobre cualesquiera propuestas de planes, programas o disposiciones de carácter general, o, en su caso, de su modificación o de su revisión, y porque la información pertinente sobre dichas propuestas sea inteligible y se ponga a disposición del público, incluida la relativa al derecho a la participación en los procesos decisorios y a la Administración pública competente a la que se pueden presentar comentarios o formular alegaciones.

b) El público tenga derecho a expresar observaciones y opiniones cuando estén abiertas todas las posibilidades, antes de que se adopten decisiones sobre el plan, programa o disposición de carácter general.

c) Al adoptar esas decisiones sean debidamente tenidos en cuenta los resultados de la participación pública.

d) Una vez examinadas las observaciones y opiniones expresadas por el público, se informará al público de las decisiones adoptadas y de los motivos y consideraciones en los que se basen dichas decisiones, incluyendo la información relativa al proceso de participación pública.

El apartado 2 establece, en aras de una "participación temprana", que las Administraciones públicas competentes "determinarán, con antelación suficiente para que pueda participar de manera efectiva en el proceso, qué miembros del público tienen la condición de persona interesada para participar en los procedimientos".

Así, la Ley deja en manos de cada Administración la determinación de los medios de comunicación que utilizará, de los plazos para garantizar una participación temprana y debidamente informada, y del alcance subjetivo del proceso de participación mediante el reconocimiento, en su caso, de la condición de "persona interesada".

En relación con este último aspecto, y al igual que el Convenio y la Directiva, la Ley distingue entre "público" en general, sin limitación, y "personas interesadas". Mientras que el trámite de información pública constituye la principal y más amplia forma de participación, abierta a las aportaciones que pueda hacer cualquier persona, el concepto de "personas interesadas" permite definir para determinados trámites cualificados un círculo más reducido, por entender que están 
especialmente afectadas, posibilitándoles una participación más intensa ${ }^{34}$. La definición de "personas interesadas" viene dada en este caso por el juego de remisiones que el artículo 2.2 establece en relación con el artículo 23 de la Ley 27/2006 IPPAJMA: según el primero, por "persona interesada" se entenderá "a) Toda persona física o jurídica en la que concurra cualquiera de las circunstancias previstas en el artículo 31 de la Ley 30/1992, de 26 de noviembre, de Régimen Jurídico de las Administraciones Públicas y del Procedimiento Administrativo Común" (referencia que hoy día tenemos que considerar hecha al artículo 4 de la Ley 39/2015 y que implica, en esencia, la afectación de un derecho o interés legítimo); y "b) Cualesquiera personas jurídicas sin ánimo de lucro que cumplan los requisitos establecidos en el artículo 23". Esta última previsión se refiere a aquellas personas a las que se reconoce el derecho de acceso a la justicia en asuntos medioambientales, que son las que reúnan los siguientes requisitos: a) que tengan entre los fines acreditados en sus estatutos la protección del medio ambiente en general o la de alguno de sus elementos en particular; b) que se hubieran constituido legalmente al menos dos años antes del ejercicio de la acción y que vengan ejerciendo de modo activo las actividades necesarias para alcanzar los fines previstos en sus estatutos; y c) que según sus estatutos desarrollen su actividad en un ámbito territorial que resulte afectado por la actuación, o en su caso, omisión administrativa. En definitiva, se consideran personas interesadas, en todo caso, las organizaciones no gubernamentales para la defensa del medio ambiente -cuya implicación el Convenio reconoce como crucial en estos procesos-, con los límites que establece el artículo 23 en cuanto a coincidencia de objetivos, continuidad y ámbito de actuación ${ }^{35}$.

Las garantías de mínimos que establece el artículo 16.1 - sin perjuicio de las dispuestas en cualquier otra disposición que amplíe los derechos reconocidos en esta ley- se aplican en la elaboración, modificación y revisión de los planes y programas sectoriales a que se refiere el artículo $17^{36}$, así como en la elaboración de las disposiciones de carácter general a que se refiere el artículo $18^{37}$, que versen sobre las materias relacionadas con la protección del medio ambiente. Por lo que respecta a la regulación de los demás ámbitos de participación previstos en el Convenio, la Ley 27/2006 se remite a la normativa sectorial correspondiente en sus artículos 3.2.e y 17.2 y, en particular, a la regulación de los procedimientos administrativos que deben tramitarse para conceder las autorizaciones ambientales integradas, para evaluar el

\footnotetext{
${ }^{34}$ Vid. RAZQUIN LIZARRAGA y RUIZ DE APODACA ESPINOSA, Información, participación... cit., 116-118.

35 Ibid., pp. 118-123.

${ }^{36} \mathrm{Vid}$., al respecto, apartado 1III.3, p. 31, infra.

${ }^{37}$ Vid., al respecto, apartado III.4, p. 37, infra.
} 
impacto ambiental de ciertos proyectos, para llevar a cabo la evaluación ambiental estratégica de determinados planes y programas, o para elaborar y aprobar los planes y programas previstos en la legislación de aguas, en los términos que se examinan a continuación.

\section{La participación pública en las decisiones sobre las actividades específicas recogidas en el anexo I del Convenio}

La participación pública en las decisiones administrativas sobre las actividades recogidas en el anexo I del Convenio se rige por la legislación sectorial que regula la autorización y el control de dichas actividades. A tales efectos, la Ley 27/2006 IPPAJMA se remite a la "legislación aplicable" en relación con "los procedimientos administrativos tramitados para el otorgamiento de las autorizaciones reguladas en la legislación sobre prevención y control integrado de la contaminación, para la concesión de los títulos administrativos regulados en la legislación en materia de organismos modificados genéticamente, y para la emisión de las declaraciones de impacto ambiental reguladas en la legislación sobre evaluación de impacto ambiental"38. Al mismo tiempo, en su disposición final única introdujo importantes modificaciones en el Real Decreto Legislativo 1302/1986, de 28 de junio, de evaluación de impacto ambiental (por el que se transpuso la Directiva 85/337/CEE EIA), y en su disposición final segunda en la Ley 16/2002, de 1 de julio, de prevención y control integrados de la contaminación (por la que se transpuso la Directiva 96/61/CE IPPC), con el objeto de incorporar en las mismas disposiciones dirigidas a garantizar la participación efectiva y temprana, así como conceptos básicos como el de "público" y "persona interesada", en línea con el Convenio y la Directiva 2003/35/CE.

La evaluación ambiental de proyectos se rige en la actualidad por la Ley 21/2013, de 9 de diciembre, de Evaluación Ambiental (en adelante, LEA), que derogó y sustituyó el Real Decreto Legislativo 1/2008, de 11 de enero, por el que se había aprobado el texto refundido de la Ley de Evaluación de Impacto Ambiental de proyectos (LEIA). Por lo que respecta a la prevención y el control integrados de la contaminación, la Ley 16/2002 ha sido derogada y sustituida, tras numerosas modificaciones, por el Real Decreto Legislativo 1/2016, de 16 de diciembre, por el que se aprueba el texto refundido de la Ley de prevención y control integrados de la contaminación (en adelante, LIPPC). Dada la especial relevancia de estas dos normas en la protección del medio ambiente y los cambios que han experimentado en los últimos años, los

\footnotetext{
${ }^{38}$ Art. 3.2.e).
} 
próximos apartados se centran en el examen de las disposiciones sobre participación que estas han establecido.

\subsection{Participación en la evaluación ambiental de proyectos}

En este ámbito, la eficacia de los mecanismos de participación articulados en nuestro ordenamiento (inicialmente regulados en el Decreto Legislativo 1302/1986 y después por la LEIA) ha sido críticamente valorada por la doctrina, que ha puesto de manifiesto en su aplicación importantes problemas de transparencia, dificultades de acceso a la información necesaria, plazos inadecuados y limitaciones de diversa índole a la hora de posibilitar una efectiva participación del público en general y los representantes de los distintos intereses afectados ${ }^{39}$.

En la actualidad la LEA consagra expresamente la participación pública como uno de los principios rectores de este instrumento de tutela ambiental ${ }^{40}$, y contiene diversas disposiciones sobre participación, conforme a las obligaciones establecidas en la actual Directiva 2011/92/UE del Parlamento Europeo y del Consejo, de 13 de diciembre de 2011, relativa a la evaluación de las repercusiones de determinados proyectos públicos y privados sobre el medio ambiente (Directiva EIA $)^{41}$. Disposiciones que, en esencia, se basan en los mismos mecanismos de participación que la legislación precedente en esta materia: los trámites de información pública y de consulta a los interesados. Por otro lado, una novedad significativa es que va a distinguir entre proyectos sometidos a evaluación de impacto ambiental (EIA) ordinaria, para los que se prevén trámites tanto de consulta como de información pública, y aquellos que están sometidos a EIA simplificada, en los que solo está prevista la consulta al público interesado. De su ámbito de aplicación quedan excluidos, no obstante, determinados proyectos en los términos que se examinan a continuación.

\footnotetext{
39 Vid. MARTÍNEZ OROZCO, J. M., "El modelo español de participación pública en la evaluación de impacto ambiental: el largo camino hacia Aarhus", Evaluación de impacto ambiental en España: nuevas perspectivas - Actas del IV Congreso Nacional de Evaluación de Impacto Ambiental, IV CONEIA, Madrid, 2008, pp. 423-430; NOGUEIRA LÓPEZ, "¿Participación efectiva..." cit., 124; VICENTE DÁVILA, F., "30 años de experiencia en la aplicación de la evaluación ambiental: La participación pública pública una asignatura pendiente”, Conference Paper, noviembre de 2015, pp. 1-2, https://www.researchgate.net/publication/284178825 30 anos de experiencia en la aplicacion de la evaluacion ambiental La participacion publica publica una asignatura pendiente [última consulta, 28 de abril de 2018]. ${ }^{40}$ Art. 2.

${ }^{41}$ Para un análisis general de esta ley, vid. GARCÍA URETA, A., "Comentarios sobre la Ley 21/2013 de Evaluación Ambiental", RAP, núm. 194, 2014, 317-371.
} 
i. La participación en la evaluación de impacto ambiental ordinaria de proyectos sujetos a autorización

En primer lugar, la LEA prevé la consulta a las partes interesadas en la elaboración del documento de alcance del estudio de impacto ambiental (scoping) por un plazo máximo de treinta días hábiles ${ }^{42}$. La elaboración de este documento -a través del cual el órgano ambiental delimita la amplitud, el nivel de detalle y el grado de especificación del estudio ambiental que debe presentar el promotor- ha dejado de ser obligatoria en la Ley 21/2013, pasando a ser potestativa a petición del promotor, en línea con lo también dispuesto por la Directiva EIA $A^{43}$. Por consiguiente, cuando no se sustancia dicha petición, se pierde la posibilidad de facilitar la participación temprana de las "personas interesadas" en el proceso. Con independencia de las críticas que en términos generales merece esta modificación ${ }^{44}$, no ha supuesto en sí misma la eliminación de un trámite de participación preceptivo: si bien es cierto que en el texto refundido de la Ley de Evaluación de Impacto Ambiental de 2008 la determinación del alcance del estudio de impacto ambiental por el órgano ambiental tenía carácter obligatorio, con las garantías que ello implicaba, solo era preceptiva la consulta a otras Administraciones afectadas, mientras que la consulta al público o a otras personas interesadas tenía carácter potestativo ("La consulta se podrá ampliar también a otras personas físicas o jurídicas, públicas o privadas, vinculadas a la protección del medio ambiente").

En segundo lugar, la LEA exige en todo caso - al igual que antes el texto refundido de 2008que el órgano sustantivo encargado de autorizar el proyecto lo someta, junto con el estudio de impacto ambiental realizado por el promotor, a información pública durante un plazo no inferior a treinta días, previo anuncio en el boletín oficial ${ }^{45}$. Introduce al respecto dos precisiones: explicita que dicho trámite se ha de llevar a cabo, en línea con las exigencias del apartado 4 del artículo 6 del Convenio, "en una fase del procedimiento sustantivo de autorización del proyecto cuando estén abiertas todas las opciones relativas al contenido, extensión y definición del proyecto"46; y contempla la publicidad, "en su caso", en la sede electrónica de la Administración competente. También precisa la información que, como mínimo, se tendrá que poner a disposición del público, incluida la identificación de aquellos órganos de los que pueda obtenerse información pertinente y de aquellos a los que puedan presentarse alegaciones, así como el plazo disponible

\footnotetext{
42 Art. 34 LEA.

${ }^{43}$ Art. 5.2 de la Directiva 2011/92/UE.

${ }^{44}$ Nogueira López califica esta disposición como "un paso atrás", dado que en la normativa vigente desde 2008 se había optado por exigir el scoping en todo caso; en "La participación en la evaluación..." cit., p. 132-133.

${ }^{45}$ Art. 36.1 LEA.

${ }^{46}$ Apartado 1 del artículo 36 LEA.
} 
para su presentación ${ }^{47}$. Además, se encomienda al órgano sustantivo, o, en su caso, al órgano ambiental, que adopte "las medidas necesarias para garantizar que la documentación que debe someterse a información pública tenga la máxima difusión entre el público, utilizando preferentemente los medios de comunicación y electrónicos" 48 , disposiciones dirigidas a paliar algunas de las deficiencias atribuidas a la aplicación de la legislación anterior.

En tercer lugar, y por lo que respecta al trámite de consulta a las personas interesadas, este se establece simultáneamente al de participación pública ${ }^{49}$, con un plazo máximo de treinta días hábiles desde la recepción de la notificación para formular alegaciones. La LEA prevé ahora, como instrumento para facilitar la identificación de las personas que puedan resultar interesadas en cada procedimiento, la creación de un registro para la inscripción de aquellos que acrediten la condición de interesados, que puede mejorar su identificación y accesibilidad a la información, y el establecimiento de mecanismos de cooperación y colaboración entre Administraciones públicas a tales efectos ${ }^{50}$.

En tercer lugar se exige, en línea con el apartado 8 del artículo 6 del Convenio, que los resultados de las consultas y de la información pública sean tomados en consideración por el promotor en su proyecto ${ }^{51}$. Al igual que ocurre también con la evaluación estratégica de planes y programas $^{52}$, la LEA encomienda ahora al órgano ambiental la tarea de velar porque la información pública y las consultas se realicen conforme a lo dispuesto en la Ley, de forma que, si durante el análisis técnico del expediente de impacto ambiental estimara que la información pública o las consultas adolecen de cualquier deficiencia, requerirá al órgano sustantivo para que subsane el expediente de impacto ambiental en el plazo de tres meses; si el órgano sustantivo no remite el expediente subsanado, "o si una vez presentado fuera insuficiente, el órgano ambiental dará por finalizada la evaluación de impacto ambientap"53. Esta cautela puede evitar, en su caso, que la autorización finalmente otorgada sin el debido respeto a las disposiciones sobre participación pueda ser impugnada y eventualmente anulada por los Tribunales ${ }^{54}$.

Por lo que respecta a las exigencias de publicidad previstas en el apartado 9 del artículo 6 del Convenio, la LEA establece que la declaración de impacto ambiental de proyectos se hará

\footnotetext{
${ }^{47}$ Apartado 2 del artículo 36 LEA.

${ }^{48}$ Apartado 3 del artículo 36 LEA.

${ }^{49}$ Art. 37 LEA.

${ }^{50}$ Disposición adicional decimocuarta.

51 Art. 38 LEA.

52 Vid. apartado III.3.

${ }^{53}$ Arts. 40.1 y 2 LEA, las itálicas son de la autora.

${ }^{54}$ Vid. apartado IV. 1 infra.
} 
pública en todo caso a través del boletín oficial correspondiente, sin perjuicio de su publicación en la sede electrónica del órgano ambiental ${ }^{55}$, e incluirá "el resumen del resultado del trámite de información pública y de las consultas a las Administraciones públicas afectadas y a las personas interesadas, y cómo se han tenido en consideración"56. Asimismo, se publicará en el plazo de quince días la decisión final de autorizar o denegar el proyecto ${ }^{57}$.

Por lo que se refiere a los casos de modificación de las condiciones de la declaración de impacto ambiental, por el contrario, solo se prevé la consulta a las personas interesadas previamente consultadas, pero no un trámite de información pública ${ }^{58}$, lo que supone en estos casos una importante limitación a la participación del público en general, en particular cuando dichas modificaciones sean sustanciales, que podría entrar en colisión con lo dispuesto en el apartado 10 del artículo 6 del Convenio (que exige que cada parte vele porque, cuando una autoridad pública reexamine o actualice las condiciones en que se ejerce una actividad comprendida en su ámbito de aplicación, se apliquen mutatis mutandis las garantías establecidas en los apartados 2 a 9 de dicho artículo).

Por otro lado, tal y como se analiza en el apartado IV infra, sigue siendo cuestionable si puede considerarse "razonable", conforme al artículo 6.3 del Convenio, un plazo "máximo" de treinta días naturales ${ }^{59}$ o la aplicación estricta de un plazo "mínimo" de treinta días ${ }^{60}$ para realizar los trámites de consulta e información pública en el caso de proyectos especialmente complejos y con gran impacto ambiental. Nótese, asimismo, que conforme a la disposición final octava LEA los plazos que se establecen en estas disposiciones $-\mathrm{y}$ en particular los dispuestos para la información pública o la consulta a las personas interesadas ${ }^{61}$ — no tienen carácter básico, lo que deja a la discrecionalidad de las comunidades autónomas la determinación de los "plazos razonables".

ii. Otros supuestos de evaluación ambiental de proyectos

\footnotetext{
55 Apartado 3 del artículo 41.

56 Apartado 2 del artículo 41 LEA. Nótese, además, que conforme al apartado 3 del artículo 83 LPCAP "quienes presenten alegaciones u observaciones en este trámite tienen derecho a obtener de la Administración una respuesta razonada, que podrá ser común para todas aquellas alegaciones que planteen cuestiones sustancialmente iguales".

57 Art. 42 LEA.

58 Art. 44 LEA.

${ }^{59}$ Art. 37 LEA.

${ }^{60}$ Art. 36 LEA.

${ }^{61}$ En los artículos 34, 36, 37 y 44 LEA.
} 
En los casos en que un proyecto es objeto de evaluación simplificada ${ }^{62}$, el trámite de información pública no está previsto, sino tan solo el de consulta a las personas interesadas ${ }^{63}$, lo que puede arrojar dudas sobre la conformidad de este procedimiento con las exigencias del artículo 6 del Convenio ${ }^{64}$.

Por lo que se refiere a los proyectos sometidos a "declaración responsable" o "comunicación previa" ${ }^{65}$ en vez de a autorización previa, estas no podrán presentarse hasta que no haya concluido la evaluación de impacto ambiental por el órgano ambiental y haya sido publicada en el diario oficial correspondiente ${ }^{66}$, recayendo sobre dicho órgano la realización de la información pública ${ }^{67}$. En estos casos parece lógico pensar que el promotor que presenta el proyecto parte de una opción predeterminada y que comunica al órgano ambiental a efectos de que este proceda a la evaluación ambiental, sin que quede claro cómo se garantiza en estos supuestos el cumplimiento de lo dispuesto en el apartado $4 .{ }^{\circ}$ del artículo 6 del Convenio, según el cual la participación debe comenzar "cuando todas las opciones y soluciones sean aún posibles y cuando el público pueda ejercer una influencia real".

iii. Los supuestos excluidos de evaluación ambiental: en particular, la aprobación de proyectos por ley

Conforme al apartado 2 del artículo 8 LEA, las disposiciones de esta ley no se aplican a los siguientes proyectos:

(a) "Los relacionados con los objetivos de la defensa nacional cuando tal aplicación pudiera tener repercusiones negativas sobre tales objetivos". Esta excepción también está prevista en el artículo 6.1.c) del Convenio y en el artículo 1.3 de la Directiva 2011/92/UE EIA, aunque en

\footnotetext{
62 Vid. los proyectos enumerados en el artículo 7.2 LEA.

${ }_{63}$ Artículo 46, que establece también un plazo de treinta días máximo, de carácter no básico, conforme a la disposición adicional octava LEA.

64 Vid. Ruiz de Apodaca, para quien la falta del trámite de información pública podría contravenir el Convenio, en RUIZ DE APODACA ESPINOSA (dir.), Régimen Jurídico... cit., p. 83.

${ }_{65}$ Conforme al apartado 1 del artículo 69 de la Ley 39/2015, de 1 de octubre, del Procedimiento Administrativo Común de las Administraciones Públicas, "se entenderá por declaración responsable el documento suscrito por un interesado en el que manifiesta, bajo su responsabilidad, que cumple con los requisitos establecidos en la normativa vigente para acceder al reconocimiento de un derecho o facultad o para su ejercicio, que dispone de la documentación que así lo acredita y que se compromete a mantener su cumplimiento durante el periodo de tiempo inherente a dicho reconocimiento o ejercicio". En cuanto a la "comunicación previa", se trata de "aquel documento mediante el que los interesados ponen en conocimiento de la Administración Pública competente sus datos identificativos y demás requisitos exigibles para el ejercicio de un derecho o el inicio de una actividad, de acuerdo con lo establecido en el artículo 70.1".

${ }^{66}$ Art. 9.2 LEA.

${ }^{67}$ Art. 36.1. Vid., al respecto, GARCÍA URETA, "Comentarios sobre la Ley 21/2013..." cit., pp. 335-337; NOGUEIRA LÓPEZ, "La participación en la evaluación...” cit., pp. 129-130.
} 
términos no exactamente coincidentes. El artículo 1.3 de la Directiva inicialmente establecía, en línea con el artículo 6.1.c) del Convenio, lo siguiente: "Los Estados miembros podrán decidir, evaluando caso por caso, si así lo dispone la legislación nacional, no aplicar la presente Directiva a los proyectos que respondan a las necesidades de la defensa nacional si consideran que esa aplicación pudiese tener repercusiones negativas respecto de dichas necesidades". El alcance de esta excepción dista de ser univoco ${ }^{68}$ y tampoco está claro en qué medida el artículo 8.2.a) LEA se adecua plenamente a las exigencias de la Directiva y del Convenio, si se interpreta en el sentido de que permite una valoración y exclusión por categorías o tipos de proyectos relacionados con la defensa nacional y no proyecto a proyecto (por entenderse que en tales casos la consecución de sus objetivos se vería siempre menoscabada por la tramitación de una evaluación ambiental). Como toda excepción, esta disposición debe ser interpretada de forma estricta, lo que permite excluir la aplicación de esta excepción por categorías o tipos de proyectos. La interpretación restrictiva del artículo 1.3 de la Directiva EIA ha llevado al Tribunal de Justicia UE a declarar, por ejemplo, que, para poder beneficiarse de esta excepción, la "finalidad principal" del proyecto ha de ser la defensa nacional y no otra ${ }^{69}$. Por otro lado, haciéndose en parte eco de esta jurisprudencia, la Directiva 2014/52/UE (aún pendiente de transposición al ordenamiento español) ha modificado el apartado 3 del artículo 1 de la Directiva 2011/92/UE EIA para precisar que se puede excepcionar la aplicación de sus disposiciones a "partes de proyectos" cuando estos tengan como "único objetivo la defensa", así como a proyectos que tengan "como único objetivo la respuesta a casos de emergencia civil" considera que su aplicación puede tener efectos adversos en tales objetivos, lo que reduce en cierto grado la discrecionalidad de los Estados miembros a la hora de aplicar esta excepción ${ }^{71}$.

(b) Una exclusión de gran calado del ámbito de aplicación de la LEA —y especialmente problemática- es la de "los proyectos detallados aprobados específicamente por una Ley". E artículo 8.1.b) LEA sujeta esta exclusión a dos requisitos: "[...] estos proyectos deben contener los datos necesarios para la evaluación de las repercusiones de dicho proyecto sobre el medio ambiente" y "en la tramitación de la Ley de aprobación del proyecto se deben cumplir los objetivos establecidos en esta Ley". Recoge así la doctrina del Tribunal de Justicia de la Unión Europea sobre las condiciones que deben cumplirse para una correcta aplicación de esta

\footnotetext{
${ }^{68}$ La propia Guía de la aplicación del Convenio de Aarhus reconoce que la redacción del artículo 6.1.c) no es nítida; sobre las distintas interpretaciones que permite esta excepción en el Convenio, vid. UNECE, The Aarhus Convention... cit., pp. 133-134.

69 Vid. STJUE de 16 de septiembre de 1999, as. C-435/97, World Wildlife Fund (WWF).

${ }^{70}$ Las itálicas son de la autora.

${ }^{71}$ Vid., para un análisis de la Directiva 2014/52/UE, GARCÍA URETA, A., "Apuntes sobre la Directiva 2014/52 de evaluación de impacto ambiental de proyectos", Ambiente y Derecho, núm. 13, 2015, pp. 39-57; p. 44.
} 
excepción, tal y como fue prevista originalmente en el artículo 1.5 de la Directiva 85/337/CEE EIA y en la actualidad en el artículo 1.4 de la Directiva 2011/92/UE EIA ${ }^{72}$.

Nótese al respecto que las disposiciones sobre participación del Convenio de Aarhus solo se aplican a las "autoridades públicas" de los Estados, concepto del que el artículo 2.2 del Convenio excluye expresamente a "los órganos o instituciones que actúen en ejercicio de poderes legislativos", por lo que las obligaciones de participación establecidas en el segundo pilar de este no son en principio aplicables en el marco de los procesos legislativos.

Se plantea así el problema de los supuestos en que la aprobación de proyectos por ley se utilice para eludir las garantías de la normativa de evaluación ambiental en detrimento de la consecución de sus objetivos. Cuestión esta que ha sido abordada por el Tribunal de Justicia de la Unión Europea en diversas ocasiones, desarrollando una importante línea jurisprudencial dirigida a evitar que, por esa vía, pueda menoscabarse el efecto útil de la normativa comunitaria relativa a la evaluación de impacto ambiental, y que ha acabado extendiendo al artículo 2.2 del Convenio. El Tribunal de Justicia de la Unión Europea ha aclarado en reiteradas ocasiones, en relación con la excepción originalmente prevista en el artículo 1.5 de la Directiva 85/337/CEE EIA, que, "cuando los objetivos esta Directiva, incluido el de la disponibilidad de informaciones, se alcanzan a través de un procedimiento legislativo, la Directiva no se aplica al proyecto de que se trate"73.También ha precisado que la exclusión de un proyecto en el ámbito de aplicación de la Directiva se sujeta a dos requisitos: "El primero es que se trate de un proyecto detallado adoptado mediante un acto legislativo específico. El segundo es que se alcancen los objetivos de la Directiva, incluido el objetivo de la disponibilidad de informaciones, a través del procedimiento legislativo"74. El Tribunal ha delimitado el concepto de "acto legislativo específico" en el sentido de que este debe presentar características similares a una autorización con arreglo al artículo 1, apartado 2, de la Directiva 85/337: "[...] el acto legislativo debe adoptar un proyecto detallado, a saber, de manera suficientemente precisa y definitiva, de modo que contenga, al igual que una autorización, todos los datos pertinentes para la evaluación de sus repercusiones sobre el medio ambiente, una vez tomados en consideración por el legislador"75. En relación con el segundo requisito, exige que "el legislador debe disponer de información suficiente en el momento de aprobar el proyecto", de manera que "la información que el titular del proyecto debe

\footnotetext{
72 Vid. STJUE de 19 de septiembre de 2000, As. C-287/98, Linster, apartado 59.

${ }^{73}$ STJUE de 19 de septiembre de 2000, as. C-287/98, Linster, apartado 51.

74 STJUE de 16 de septiembre de 1999, as. C-435/97, WWF y otros, apartado 57.

${ }^{75}$ Vid., en este sentido, las SSTJUE en el as. C-435/97, WWF y otros, cit., apartados 58 y 59 ; de 18 de octubre de 2011, as. C-128/09 a C-131/09, C-134/09 y C-135/09, Boxus y otros, apartados 38 y 39; y de 17 de noviembre de 2016, as. C 348/15, Stadt Wiener Neustadt y Niederösterreichische Landesregierung y otros, apartado 27.
} 
proporcionar contendrá al menos una descripción del proyecto que incluya información relativa a su emplazamiento, diseño y tamaño, una descripción de las medidas previstas para evitar, reducir y, si fuera posible, compensar, los efectos adversos significativos, así como los datos requeridos para identificar y evaluar los principales efectos que el proyecto pueda tener en el medio ambiente"76.

En el asunto Boxus el TJUE dio un nuevo paso de gran importancia al declarar —a la luz del artículo 9 del Convenio de Aarhus y del entonces artículo 10 bis de la Directiva 85/337- que, cuando un proyecto comprendido dentro del ámbito de aplicación del artículo 6 del Convenio de Aarhus o de la Directiva sea adoptado mediante un acto legislativo, la cuestión de si dicho acto legislativo se ajusta a los requisitos ya expuestos para que sea aplicable la excepción "debe poder ser objeto de un control, con arreglo a las normas de procedimiento nacionales, por un órgano jurisdiccional o por un órgano independiente e imparcial establecido por la ley"77. Doctrina esta que el Tribunal ha acabado extendiendo a lo dispuesto por el artículo 2.2 del Convenio de Aarhus en el asunto Solvay. Así, según el Tribunal:

Esa solución, enunciada en la sentencia Boxus y otros, antes citada, acerca del artículo 1, apartado 5, de la Directiva 85/337, puede extenderse al artículo 2, apartado 2, del Convenio de Aarhus. En efecto, el artículo 2, apartado 2, de ese Convenio tiene en sustancia un contenido idéntico al del artículo 1, apartado 5, de dicha Directiva. Por otro lado, del objeto o del alcance del Convenio de Aarhus no puede deducirse razón alguna que se oponga a que el Tribunal de Justicia extienda a la interpretación de las disposiciones de dicho Convenio la interpretación que ha enunciado para las disposiciones similares de la Directiva $85 / 337^{78}$.

Los pronunciamientos del TJUE en los asuntos Boxus y Solvay contribuyen, sin duda, a garantizar la eficacia de las disposiciones del Convenio y de la ahora Directiva 2011/92/UE sobre evaluación de impacto ambiental a través del control judicial de la correcta aplicación de la excepción prevista para los proyectos aprobados mediante un acto legislativo. No obstante, suscitan al mismo tiempo importantes cuestiones - y retos - sobre cómo puede aplicarse en nuestro ordenamiento dicha doctrina, dado que, conforme a la Constitución, únicamente el Tribunal Constitucional puede enjuiciar las leyes, y solo con la finalidad de verificar su conformidad a la Carta Magna ${ }^{79}$. Entre la doctrina española el debate se ha visto avivado por los

\footnotetext{
76 SSTJUE as. C-128/09 a C-131/09, C-134/09 y C-135/09, Boxus y otros, cit., apartado 43, y as. C 348/15, Stadt Wiener Neustadt y Niederösterreichische Landesregierung y otros, cit., apartado 27.

77 STJUE as. C-135/09, Boxus y otros, cit., apartado 54.

78 STJUE de 16 de febrero de 2012, as. C-182/10, Solvay y otros, apartado 42.

79 Vid., para un comentario de dicha sentencia, GARCÍA-ÁLVAREZ GARCÍA, G., "Acceso a la información, participación pública y acceso a la justicia en cuestiones ambientales: del Convenio de Aarhus a la Sentencia Boxus", Revista Aragonesa de Administración Pública, XIV, 2013, pp. 433-472; GARCÍA URETA, A., "Convenio de Aarhus y convalidaciones legislativas: ¿Recurso directo contra leyes en vía contenciosa?, Comentario a la
} 
recientes pronunciamientos del propio Tribunal Constitucional sobre las leyes singulares ${ }^{80}$, en los que se han perfilado los requisitos que estas deben cumplir para ser consideradas conforme a la Constitución ${ }^{81}$, que implican —como reitera en la reciente STC 42/2018 de 26 de abril-que en cada caso "ha de valorarse su incidencia 'de forma directa, aunque no necesariamente ilegítima, en el derecho a la tutela judicial efectiva', en cuanto pueda 'impedir el acceso al control judicial de derechos e intereses legítimos afectados y eliminar la posibilidad de un control judicial de la misma intensidad que hubieran podido realizar los Tribunales de la jurisdicción contencioso-administrativa"'.

Pronunciamiento este que, leído conjuntamente con la doctrina Boxus y Solvay, puede conducir a la conclusión, tal y como apunta SANTAMARÍA ARINAS ${ }^{82}$, de que en España no cabe aprobar mediante ley singular los proyectos sometidos a evaluación de impacto ambiental conforme a la Directiva comunitaria y al Convenio de Aarhus.

Si dicha solución no fuera la que finalmente acabe implantándose, la participación del público en la adopción de aquellos proyectos que vayan a ser aprobados en un acto legislativo podría sustanciarse, en primer lugar, en la fase de elaboración del proyecto de ley en los términos del artículo 133 LPAC y del artículo 26 de la Ley 50/1997, de 27 de noviembre, del Gobierno, que se analizan en un apartado posterior; $y$, después, en sede parlamentaria a través de la comparecencia de personas o entidades interesadas conforme permiten los reglamentos parlamentarios $^{83}$. Vía esta por la que quedaría sin resolver, sin embargo, el problema de la aplicación de la doctrina Boxus y Solvay en nuestro ordenamiento. Además, como CUBERO

sentencia del TJUE (Gran Sala) de 18 de octubre de 2011, Boxus v. Regione Wallone, asuntos acumulados C128/09 a C-131/09, C134/09 y C-135/09", Diario La Ley, núm. 7763, Sección Doctrina, 27 de diciembre de 2011, año XXXII, ref. D-482.

$80 \mathrm{Vid}$. CUBERO MARCOS, J. I., "Proyectos y planes aprobados por Ley: contradicción a la luz de la evaluación ambiental, el derecho de participación y acceso a la justicia en materia ambiental", RVAP, núm. 99-100, 2014, pp. 1007-1039; GARCÍA URETA, "Comentarios sobre la Ley 21/2013..." cit., pp. 333-334; LÓPEZ RAMÓN, F., "Introducción general: perplejidades en el años de Fukushima", AA. VV., Observatorio de Políticas Ambientales 2012, Thomson-Aranzadi, Cizur Menor, 2012, pp. 43-46; NOGUEIRA LÓPEZ, "La participación en la evaluación..." cit., pp. 140-142; SANTAMARÍA ARINAS, R. J., "Leyes singulares, tutela judicial efectiva y recepción de la doctrina 'Boxus' por el Tribunal Constitucional español”, RAP, núm. 193, 2014, pp. 165-195.

81 Vid. las SSTC 129/2013 y 203/2013, entre otras. Según dicha doctrina, para que una ley singular sea conforme con la Constitución ha de cumplir los siguientes requisitos: en primer lugar, debe "responder a una situación excepcional igualmente singular"; en segundo lugar, "debe estar circunscrita a aquellos casos excepcionales que, por su extraordinaria trascendencia y complejidad, no son remediables por los instrumentos normales de que dispone la Administración, constreñida a actuar con sujeción al principio de legalidad, ni por los instrumentos normativos ordinarios, haciéndose por ello necesario que el legislador intervenga singularmente, al objeto exclusivo de arbitrar una solución adecuada, a una situación singular"; y, finalmente, "no es posible condicionar o impedir por una ley singular el ejercicio de derechos fundamentales que son materia reservada a leyes generales".

82 SANTAMARÍA ARINAS, "Leyes singulares..." cit. p. 192.

${ }^{83}$ RAZQUIN LIZARRAGA, M. M., "La evaluación ambiental: Tipos, Ámbito de Aplicación e Interrelación", Ruiz de Apodaca Espinosa, A. (dir.), Régimen Jurídico de la Evaluación Ambiental, Comentario a la Ley 21/2013, de 9 de diciembre, de evaluación ambiental, Thomson Reuters, Cizur Menor, 2014, p. 186. 
MARCOS ha puesto de relieve, estos mecanismos no son comparables a los establecidos en el marco de la evaluación de impacto ambiental que lleva a cabo la Administración, siendo necesario "articular, como garantía de la efectividad de la participación, el vínculo o relación que ha de mediar entre las actuaciones administrativas, como la declaración de impacto o estratégica, o los informes, y la posterior decisión en sede legislativa"84. Hay que tener en cuenta, no obstante, que la Directiva de EIA no está evolucionando precisamente en este sentido, puesto que en las últimas modificaciones introducidas por la Directiva 2014/52/UE — aún pendiente de ser transpuesta a nuestro ordenamiento- se permite a los Estados miembros excluir la aplicación de las disposiciones sobre consulta pública en los casos en los que se apruebe un proyecto mediante un acto legislativo nacional específico, "siempre que se cumplan los objetivos de la presente Directiva" 85 . Exige, no obstante, que los Estados miembros informen de la aplicación de esta excepción cada dos años a la Comisión ${ }^{86}$.

\subsection{Participación en las autorizaciones integradas}

Como ya hemos señalado, la participación en el procedimiento de autorización de actividades recogidas en el anexo I del Convenio de Aarhus se garantiza también a través de la normativa que regula la concesión de autorizaciones ambientales integradas (AAI). Las disposiciones de la Ley 16/2002, de 1 de julio, de prevención y control integrados de la contaminación — por la que inicialmente se transpuso la Directiva 96/61/CE-, y sus sucesivas modificaciones están ahora recogidas en el texto refundido de la Ley de prevención y control integrados de la contaminación (LIPPC), aprobado Real Decreto Legislativo 1/2016, de 16 de diciembre ${ }^{87}$.

La LIPPC exige a las Administraciones públicas que promuevan la "participación real y efectiva de las personas interesadas en los procedimientos de otorgamiento, modificación sustancial, y revisión de la autorización ambiental integrada de una instalación”; asimismo, deben garantizar que la participación tenga lugar "desde las fases iniciales de los respectivos procedimientos" 88.

\footnotetext{
84 Vid. CUBERO MARCOS, "Proyectos y planes..." cit., p. 1037.

85 Directiva 2014/52/UE del Parlamento Europeo y del Consejo, de 16 de abril de 2014, por la que se modifica la Directiva 2011/92/UE, relativa a la evaluación de las repercusiones de determinados proyectos públicos y privados sobre el medio ambiente, artículo 1.2.c), que introduce un nuevo apartado 5 en el ahora artículo 2 de la Directiva 2011/92/UE.

${ }^{86}$ Para una crítica, vid. CUBERO MARCOS, "Proyectos y planes..." cit., p. 1017.

${ }^{87}$ Conforme a su artículo 2, dicha Ley es "aplicable a las instalaciones de titularidad pública o privada en las que se desarrolle alguna de las actividades industriales incluidas en las categorías enumeradas en el anejo 1 y que, en su caso, alcancen los umbrales de capacidad establecidos en el mismo, con excepción de las instalaciones o partes de las mismas utilizadas para la investigación, desarrollo y experimentación de nuevos productos y procesos".

${ }^{88}$ Art. 14 LIPPC.
} 
En concreto, impone un trámite de información pública que "no será inferior a treinta días" 89 , cuya regulación se precisa en el anejo IV de la Ley, en el que se recogen, entre otras exigencias, las de información activa, participación temprana y toma en consideración de los resultados de las consultas celebradas por el órgano competente a la hora de resolver la solicitud. Finalmente, el órgano competente debe hacer públicas las resoluciones administrativas mediante las que se hubieran otorgado o modificado las autorizaciones ambientales integradas, y poner a disposición del público el contenido de la decisión acompañada de una memoria en la que se recojan los principales motivos y consideraciones en los que se basa la resolución administrativa, incluyendo la información relativa al proceso de participación pública ${ }^{90}$.

No obstante, tal y como se pondrá de relieve al examinar las comunicaciones al Comité de Cumplimiento del Convenio de Aarhus, se ha cuestionado la adecuación al Convenio de lo dispuesto en la disposición transitoria primera de la Ley (introducida inicialmente en la Ley 16/2002, de 1 de julio, de prevención y control integrados de la contaminación, por la Ley 5/2013, de 11 de junio, que la modificó con el objeto de adecuarla a la Directiva 2010/75/UE del Parlamento Europeo y del Consejo, de 24 de noviembre de 2010, sobre las emisiones industriales, y que se recoge en los mismos términos en la actualidad en la disposición transitoria primera del Real Decreto Legislativo 1/2016). Dicha disposición establece un procedimiento de actualización de las autorizaciones ya otorgadas en virtud del cual el órgano ambiental competente comprobará de oficio, mediante un procedimiento simplificado, la adecuación de la autorización a las prescripciones de la nueva Directiva, sin que se prevea ningún trámite de información pública ${ }^{91}$. El apartado 10 del artículo 6 del Convenio establece, sin embargo, que, cuando una autoridad pública "reexamine o actualice" las condiciones en que se ejerce una actividad de las incluidas en el apartado 1 de dicha disposición, todas las disposiciones sobre participación que se establecen en los apartados 2 a 9 del mismo artículo se aplicarán "mutatis mutandis y como corresponda"92.

\footnotetext{
${ }^{89}$ Art. 16 LIPPC.

90 Art. 24 LIPPC.

91 Vid. apartado IV.2.b infra.

${ }^{92}$ Vid. el apartado IV, 2.iii supra sobre la comunicación ACCC/C/2014/122, elevada al Comité de Cumplimiento del Convenio por el Instituto Internacional de Medio Ambiente en relación con la infracción de esta disposición del Convenio por la disposición transitoria primera de la LIPPC.
} 


\section{La participación en la adopción de planes y programas}

Las disposiciones sobre participación reguladas en el artículo 16 de Ley 27/2006 IPPAJMA se aplican, como ya hemos mencionado, a los planes adoptados en las materias que enumera el apartado 1 del artículo 17 de la misma Ley: residuos, pilas y acumuladores, nitratos, envases, calidad del aire y las que se establezcan en la normativa autonómica. En consecuencia, en estos ámbitos la legislación sectorial se limita generalmente a remitirse a lo dispuesto en la Ley 27/2006 IPPAJMA ${ }^{93}$.

Por lo que se refiere a dos ámbitos especialmente relevantes en nuestro ordenamiento, el de los planes sometidos a evaluación ambiental estratégica y el de la planificación hidrológica, el apartado 2 del artículo 17 de la Ley 27/2006 IPPAJMA se remite, por el contrario, a su legislación específica, que en los últimos años ha experimentado notables cambios impulsados por el derecho de la Unión Europea y que han tenido como elemento común la articulación de nuevas disposiciones sobre participación pública en los términos que a continuación se examinan.

\subsection{La participación en la adopción de planes y programas sujetos a evaluación estratégica}

La Ley 9/2006, de 28 de abril, sobre evaluación de los efectos de determinados programas en el medio ambiente, que reguló por vez primera en nuestro país la evaluación ambiental estratégica, estableció un régimen de participación que ha sido calificado como "particularmente generoso" por la doctrina ${ }^{94}$. Esta ley, adoptada para transponer la Directiva 2001/42/CE, relativa a la evaluación de los efectos de determinados planes y programas en el medio ambiente, fue derogada por la Ley 21/2013, de 9 de diciembre, de evaluación ambiental (LEA), que vino a unificar en un solo texto la regulación de evaluación ambiental estratégica y la evaluación de impacto ambiental de proyectos. Un texto que también contiene disposiciones detalladas para facilitar la participación del público en el proceso de evaluación de aquellos planes y programas —así como de sus modificaciones- que se adopten o aprueben por una Administración pública y cuya elaboración y aprobación venga exigida por una disposición legal o reglamentaria o por acuerdo del Consejo de Ministros o del Consejo de Gobierno de una comunidad autónoma, distinguiéndose ahora entre los planes y programas que se someten a una evaluación

\footnotetext{
93 Vid., por ejemplo, el artículo 10 de la Ley 22/2011, de 28 de julio, de residuos y suelos contaminados. Para un análisis crítico, vid. ALENZA GARCÍA, J.F., "La participación en la planificación de residuos", Revista Aranzadi de Derecho Ambiental, núm 36, 2017.

94 JARIA I MANZANO, J., "La participación del público en la evaluación ambiental estratégica", Revista Aranzadi de Derecho Ambiental, núm. 11/2007, 1 parte, Crónicas, p. 9.
} 
estratégica ordinaria ${ }^{95}$ y aquellos otros que, por su menor entidad, se someten a un procedimiento de evaluación estratégica simplificada ${ }^{96}$. Al igual que ocurre en relación con la evaluación ambiental de proyectos, en este último caso la participación se limita a las personas interesadas, y lo mismo ocurre en caso de modificación de la evaluación ambiental ordinaria, en detrimento de la consecución del objetivo de una participación efectiva en estos supuestos.

En el ámbito de la evaluación ambiental estratégica ordinaria, la primera ocasión de participación se produce en el marco de la elaboración del documento de alcance del estudio ambiental estratégico (scoping) ${ }^{97}$ : el órgano ambiental somete el borrador a consultas previas a las personas interesadas (facilitando así su participación temprana), que tienen un plazo para pronunciarse de cuarenta y cinco días hábiles desde su recepción; recibidas las contestaciones a las consultas, dicho órgano elaborará y remitirá al promotor y al órgano sustantivo responsable de aprobar el plan o programa el documento de alcance del estudio ambiental estratégico, junto con las contestaciones recibidas a las consultas realizadas ${ }^{98}$, poniéndose el documento de alcance del estudio ambiental estratégico a disposición del público a través de la sede electrónica del órgano ambiental99. A diferencia de lo ahora dispuesto en relación con la evaluación de impacto ambiental de proyectos, en que, como vimos, las consultas no eran preceptivas, en el caso de la evaluación estratégica sí se posibilita la participación temprana a las personas interesadas en la etapa de elaboración del documento de alcance del estudio ambiental estratégico. En cuanto al desarrollo y resultado de los trámites de información pública y de consulta de las versiones iniciales de los planes y programas, siguen un patrón similar al ya examinado para la evaluación ambiental de proyectos ${ }^{100}$, si bien con algunas diferencias, entre

\footnotetext{
${ }^{95}$ Apartado 1 del artículo 6 LEA.

${ }^{96}$ Apartado 2 del artículo 6 LEA.

${ }^{97}$ Apartado 1 del artículo 19 LEA.

${ }^{98}$ Apartado 2 del artículo 19 LEA.

${ }^{99}$ Apartado 3 del artículo 19 LEA.
}

$100 \mathrm{Al}$ igual que en la evaluación ambiental de proyectos, en el caso de la evaluación ambiental estratégica la versión inicial del plan o programa elaborado por el promotor se somete a información pública, acompañada del correspondiente estudio ambiental estratégico, si bien por un plazo algo más amplio (un "plazo mínimo de 45 días hábiles" previo anuncio en el boletín oficial correspondiente), y, "en su caso, en su sede electrónica" (art. 21.2). También se exige al órgano competente que adopte las medidas necesarias para garantizar que tenga la "máxima difusión" (art. 21.4). Simultáneamente a la información pública tiene lugar un trámite de consulta a las personas interesadas, que dispondrán de otro plazo mínimo de cuarenta y cinco días hábiles para hacer alegaciones (art. 22.1 y 2). Por su parte, el artículo 23 dispone igualmente que las alegaciones formuladas en los trámites de información pública y consultas deberán ser tomadas en consideración por las autoridades competentes en la elaboración de la propuesta final del plan o programa, y deberán ser tomadas en consideración, asimismo, durante el análisis técnico del expediente por el órgano ambiental (art. 24.1.d). Del mismo modo que en la evaluación ambiental de proyectos, la Ley también encomienda al órgano ambiental velar por el correcto desarrollo de la participación, de modo que, si durante el análisis técnico del expediente estimara que la información pública o las consultas no se han realizado conforme a lo establecido en la Ley, requerirá al órgano sustantivo para que subsane el expediente de evaluación ambiental estratégica en el plazo máximo de tres meses (art. 24.3). En el caso de que este no lo remitiera subsanado en plazo, o si una vez presentado fuera insuficiente, el órgano ambiental dará por 
las que destacan las relacionadas con los plazos (más amplios, al establecer plazos mínimos de cuarenta y cinco días hábiles), en algunos casos de naturaleza básica. De este modo, el plazo dispuesto para las consultas a las personas interesadas previsto en la elaboración del documento de alcance no tiene carácter básico ${ }^{101}$, aunque sí lo tienen, sin embargo, los plazos para los trámites de información pública y consulta previstos en relación con la versión inicial del plan o programa ${ }^{102}$, sin que exista una razón evidente que justifique este trato diferente dentro del mismo procedimiento de evaluación estratégica, ni en relación con los plazos establecidos a estos efectos en el caso de la evaluación de impacto ambiental de proyectos (a los que, como hemos visto, no se les reconoce carácter básico).

Se facilita así, en línea con lo dispuesto en el artículo 7 del Convenio de Aarhus, un marco de información y participación, tanto a las personas interesadas como al público en general, que posibilita la implicación de los titulares de los diversos intereses afectados y de la sociedad en su conjunto en unos procesos de programación o planificación con un importante impacto en su modelo de desarrollo. Si bien, en función de la complejidad e impacto de ciertos planes y programas, sigue estando en cuestión, como se analiza en el apartado IV infra, si la LEA garantiza el establecimiento de "plazos razonables" para la participación, como exigen los artículos 7 y 6.3 del Convenio.

Por otro lado, las opciones de participación se reducen notablemente —al igual que vimos que ocurría en relación con la evaluación ambiental de proyectos- tanto en los casos de modificación de la declaración ambiental estratégica como en los casos de evaluación ambiental estratégica simplificada:

(a) En relación con la modificación de la declaración ambiental estratégica, se prevé tan solo la consulta a las "personas interesadas previamente consultadas"103. Dado que la modificación está prevista para casos en que "concurran circunstancias que determinen la incorrección de la

finalizada la evaluación ambiental estratégica. La declaración ambiental estratégica que adopte el órgano ambiental ha de contener, conforme al artículo 25, una exposición de los hechos que resuma los principales hitos del procedimiento, entre los que se incluyen los resultados de la información pública y las consultas (apartado 2), y, una vez formulada, debe ser publicada en el diario oficial correspondiente, "sin perjuicio de su publicación en la sede electrónica del órgano ambiental" (apartado 3). Finalmente, conforme al artículo 26, el promotor deberá incorporar el contenido de la declaración ambiental estratégica en el plan o programa al someterlo a adopción o aprobación por el órgano sustantivo (apartado 1), y la resolución por la que se adopta o aprueba el plan o programa deberá ser publicada en un plazo de quince días - junto con una referencia a la dirección electrónica en la que el órgano sustantivo pondrá a disposición del público el contenido íntegro- acompañada de un extracto que dé cuenta, entre otros aspectos, de los resultados de la información pública y de las consultas. Disposiciones estas que permitirán al público hacer seguimiento del plan.

${ }_{101}$ Conforme al apartado 2.b) de la disposición final octava LEA, en relación con el artículo 19.1 LEA.

$102 \mathrm{El}$ apartado 2.b) de la disposición final octava no incluye en la enumeración de plazos que declara que carecen de carácter básico los previstos en los artículos 21 y 22 LEA.

${ }^{103}$ Apartado 4 del artículo 28 LEA. 
declaración ambiental estratégica", la omisión de un trámite de información pública complementario cuando la modificación sea sustancial puede acarrear de facto la falta de una participación del público real y efectiva en el proceso de adopción del plan o programa afectado. No obstante, tal omisión no entra en colisión con ninguna de las obligaciones que el artículo 7 del Convenio impone a las partes en relación con la participación del público en los planes y programas, ya que a estos no se les aplican las exigencias del apartado 9 del artículo 6 del Convenio, previsto únicamente para la revisión de las decisiones reguladas en dicho artículo.

(b) Por lo que se refiere a los planes y programas que quedan sometidos al procedimiento de evaluación ambiental estratégica simplificada, se prevé únicamente un trámite de consulta a las "personas interesadas" en relación con el documento ambiental estratégico y el borrador del plan o programa, con un plazo "máximo" de cuarenta y cinco para pronunciarse ${ }^{104}$, pero no se establece en este caso un trámite de información pública. Limitación que, al igual que señalamos respecto a la evaluación de impacto ambiental simplificada ${ }^{105}$, no responde a lo dispuesto en el artículo 7 en relación con los apartados 3, 4 y 8 del artículo 6 del Convenio.

Por último, hay que tener en cuenta que la LEA excluye de su ámbito de aplicación los planes y programas "que tengan como único objeto la defensa nacional o la protección civil en casos de emergencia" y los de "tipo financiero o presupuestario"106, en línea con el ámbito de aplicación definido para la evaluación estratégica en la Directiva 2001/42/CE, que también los excluye ${ }^{107}$. El Convenio, sin embargo, no incluye una excepción similar, si bien cabría entender que estos planes quedan fuera del concepto de "planes y programas relativos al medio ambiente" que utiliza el Convenio y cuyo alcance no define.

\subsection{La participación en el segundo ciclo de planificación hidrológica}

La planificación hidrológica se concibe en la Ley 29/1985, de 2 de agosto, de Aguas, como instrumento indispensable para articular una gestión racional y ordenada de los recursos hídricos, garantizando la satisfacción de las demandas existentes, sin perjuicio del buen estado ecológico de las aguas y del medio ambiente. Si bien en el derecho español ha existido una larga tradición de participación pública en materia de aguas, la normativa vigente en estos momentos es la derivada de la transposición a nuestro ordenamiento de la Directiva Marco del

\footnotetext{
${ }^{104}$ Art. 30 LEA.

105 Vid. p. 26.

${ }^{106}$ Art. 8 LEA.

${ }^{107}$ Artículo 3.8 Directiva 2001/42/CE del Parlamento Europeo y del Consejo, de 27 de junio de 2001, relativa a la evaluación de los efectos de determinados planes y programas en el medio ambiente.
} 
Agua mediante la Ley 62/2003, de 30 de diciembre, de medidas fiscales, administrativas y del orden social, que introdujo nuevas disposiciones en cuanto a la información y participación pública en lo que a la planificación hidrológica se refiere. De este modo, conforme al artículo 41.3 del texto refundido de la Ley de Aguas (TRLA): "Se garantizará en todo caso, la participación pública en todo el proceso planificador, tanto en las fases de consultas previas como en las de desarrollo y aprobación o revisión del plan". Si bien el artículo 41 TRLA remite a la vía reglamentaria la regulación de dicho procedimiento, el legislador ha exigido que esta contemple, en todo caso, "la programación de calendarios, programas de trabajo, elementos a considerar y borradores previos para posibilitar una adecuada información y consulta pública desde el inicio del proceso". Además, en los planes hidrológicos se deben incluir un resumen de las medidas de información pública y de las consultas realizadas, sus resultados y los cambios consiguientes efectuados en el plan durante dicho proceso ${ }^{108}$, para garantizar así que se conozca en qué medida las observaciones o alegaciones que hayan formulado los particulares han sido tomadas en consideración por la Administración. Por lo que se refiere a la participación orgánica, se modifica la regulación del Consejo del Agua de la cuenca (ahora Consejo del Agua de la demarcación) para definirlo como "órgano de participación y planificación”109, y, consecuentemente, para incluir entre sus funciones el fomento de la información, consulta pública y participación activa en el proceso planificador que lleva a cabo este órgano ${ }^{110}$. Finalmente, la Ley también precisa que, antes de iniciarse el procedimiento para la aprobación o revisión del correspondiente plan hidrológico, el organismo de cuenca —o Administración hidráulica competente de la comunidad autónoma- debe comenzar a publicar y poner a disposición del público, de forma escalonada y en unos plazos muy amplios (de hasta tres años), una serie de documentos con el fin de facilitar su ulterior participación durante el procedimiento (un calendario y un programa de trabajo con indicación de las fórmulas de consulta que se adoptarán en cada caso, un esquema provisional de los temas importantes que se plantean en la cuenca hidrográfica $y$, finalmente, el proyecto de plan hidrológico de cuenca) $)^{111}$.

El Reglamento de la Planificación Hidrológica (RPH) de 2007, aprobado por Real Decreto 907/2007, de 6 de julio, en desarrollo del artículo 41 TRLA, dedica su título segundo a regular el proceso de elaboración y aprobación de los planes hidrológicos, en el que se precisan las medidas de organización y procedimiento para hacer efectiva la participación pública, mediante

\footnotetext{
${ }^{108}$ Apartado 1.i) del artículo 42 TRLA.

${ }^{109}$ Apartado 3 del artículo 26 TRLA.

110 Art. 35 TRLA.

111 Disposición adicional $12 .^{\text {a }}$ del TRLA.
} 
los trámites de información y consulta pública y el fomento de la "participación activa" de las partes interesadas y del público en general ${ }^{112}$. Conforme a estas disposiciones, los organismos de cuenca formularán un "proyecto de organización y procedimiento a seguir para hacer efectiva la participación pública en el proceso de planificación"113. El proceso de elaboración de los planes incorporará los requerimientos establecidos en la Ley 27/2006 IPPAJMA, en particular aquellos referentes al suministro activo de información sustantiva para el proceso de planificación que resulte adicional a la recogida en el reglamento; información que debe estar accesible para el público en papel y en formato digital a través de las páginas electrónicas del ministerio competente en materia de medio ambiente ${ }^{114}$. La consulta pública se llevará a cabo sobre la base de los diversos documentos cuya elaboración está prevista a lo largo de las distintas etapas en las que se articula la confección de los planes hidrológicos de cuenca ${ }^{115}$. Con carácter previo a la elaboración y/o propuesta de revisión del plan hidrológico, se preparará un programa de trabajo que incluya un calendario sobre las fases previstas para dicha elaboración o revisión ${ }^{116}$ y el estudio general de la demarcación. Posteriormente, en una primera etapa, se elaborará un esquema de los temas más importantes en materia de gestión de las aguas de la demarcación ${ }^{117}$, a la que seguirá otra fase de redacción del proyecto de plan propiamente dicho ${ }^{118}$. Ultimadas las consultas de esta segunda etapa, los organismos de cuenca realizarán un informe sobre las propuestas, observaciones y sugerencias que se hubiesen presentado e incorporarán las que, en su caso, consideren adecuadas ${ }^{119}$. En este caso, en línea con las exigencias del artículo 14.2 de la Directiva Marco del Agua, el RPH prescribe plazos particularmente amplios para las consultas previstas en la elaboración de los planes hidrológicos (un mínimo de seis meses) ${ }^{120}$. Por otro lado, los proyectos de planes hidrológicos son también objeto del procedimiento de evaluación ambiental estratégica, por lo que los organismos de cuenca han de articular medidas de coordinación, las cuales también afectan a los mecanismos de participación ${ }^{121}$.

\footnotetext{
112 Vid. artículos 72 a $75 \mathrm{RPH}$.

113 Vid. artículo $72 \mathrm{RPH}$.

114 Art. $73 \mathrm{RPH}$.

115 Art. $76 \mathrm{RPH}$.

116 Art. $77 \mathrm{RPH}$.

117 Art. $79 \mathrm{RPH}$.

118 Art. $80 \mathrm{RPH}$.

119 Apartado 4 del artículo $80 \mathrm{RPH}$.

${ }^{120}$ Apartado 2 del artículo 74 y apartado 3 del artículo $80 \mathrm{RPH}$.

${ }^{121}$ Apartado 6 del artículo 71 en relación con el apartado 2.b) del artículo $72.2 \mathrm{RPH}$.
} 
Los planes hidrológicos aprobados en España a partir de 2010 — con retraso sobre el calendario establecido por la Directiva Marco del Agua ${ }^{122}$ - se han tramitado conforme a estas disposiciones $^{123}$, y los reales decretos por los que se aprueban realizan en sus respectivas exposiciones de motivos una sucinta referencia a los trámites de información pública, consulta y participación activa celebrados durante el procedimiento de elaboración de los planes de cada cuenca $^{124}$. Algunos estudios en los que se ha evaluado la participación pública en distintos momentos del proceso de planificación han destacado que, en general, la aplicación de las disposiciones a las que hemos hecho referencia ha supuesto un impulso a la democratización de la gestión del agua, dotando al proceso de una mayor transparencia para las personas interesadas y el público en general (especialmente a través de Internet); no obstante, también han puesto de relieve importantes puntos débiles y cuestiones a mejorar en el futuro para la consecución de una participación suficientemente amplia y efectiva por parte de actores sin intereses económicos y por el público en general ${ }^{125}$.

\section{La participación en la elaboración de disposiciones generales}

De acuerdo con el artículo 18 de la Ley 27/2006 IPPAJMA, las Administraciones públicas "asegurarán" que se observen las garantías en materia de participación establecidas en el artículo 16 de esta ley en relación con la elaboración, modificación y revisión de las disposiciones de carácter general que versen sobre las materias que enumera: protección de las

\footnotetext{
${ }^{122}$ La adopción de los nuevos planes con retraso sobre el calendario previsto por la Directiva Marco del Agua (cuyo artículo 13.6 establecía que debían publicarse a más tardar nueve años después de la entrada en vigor de la Directiva) dio lugar a la STJUE de 4 de octubre de 2012, en el as. C-403/11, Comisión c. España, en la que se declaró el incumplimiento de varias disposiciones de dicha Directiva, entre ellas, el artículo 14.1.c), al no haberse iniciado a más tardar el 22 de diciembre de 2008 - con algunas excepciones- el procedimiento de información y consulta públicas sobre los proyectos de los planes hidrológicos de cuenca. Dicho artículo establece que los Estados fomentarán la "participación activa de todas las partes interesadas, en particular en la elaboración, revisión y actualización de los planes hidrológicos de cuenca", y que "velarán por que, respecto de cada demarcación hidrográfica, se publiquen y se pongan a disposición del público, incluidos los usuarios, a fin de recabar sus observaciones, entre otros documentos, ejemplares del proyecto de plan hidrológico de cuenca, al menos un año antes del inicio del período al que se refiera el plan".

${ }^{123}$ Sobre los nuevos planes hidrológicos, vid., en general, EMBID IRUJO, A., "Valoración global del nuevo ciclo de la planificación hidrológica, con atención especial al Plan Hidrológico de la parte española de la demarcación hidrográfica del Ebro", Embid Irujo, A. (dir.) El segundo ciclo de planificación hidrológica en España (2010-2014), Thomson-Aranzadi, Madrid, 2015, pp. 61-77.

124 Vid., por ejemplo, la exposición de motivos del Real Decreto 478/2013, de 21 de junio, por el que se aprueba el Plan Hidrológico de la parte española de la Demarcación Hidrográfica del Duero, o del Real Decreto 129/2014, de 28 de febrero, por el que se aprueba el Plan Hidrológico de la parte española de la Demarcación Hidrográfica del Ebro.

${ }_{125}$ Vid. ESPLUGA, J., BALLESTER, A., HERNÁNDEZ-MORA, N. y SUBIRATS, J., "Participación pública e inercia institucional en la gestión del agua en España", núm. 134, 2011, Revista Española de Investigaciones Sociológicas, pp. 11-12; LEMA BLANCO, I. y GARCÍA MIRA, R., "Participación Pública en la Gestión del Agua. Un análisis de los procesos participativos desarrollados sobre los planes hidrológicos de las cuencas gallegas", Administración \& Ciudadanía, vol. 8, núm. 2, 2013, pp. 9-24, p. 12.
} 
aguas, de los suelos y contra el ruido, contaminación atmosférica, ordenación del territorio rural y urbano, conservación de la naturaleza y biodiversidad, montes, gestión de los residuos, productos químicos, biotecnología, emisiones, vertidos y liberación de sustancias en el medio ambiente, evaluación de impacto ambiental, e información, participación y acceso a la justicia en materia de medio ambiente; a lo que añade "aquellas otras que establezca la normativa autonómica". Se excepcionan, no obstante, las siguientes disposiciones generales: a) las que tengan por objeto la regulación de materias relacionadas exclusivamente con la defensa nacional, con la seguridad pública, con la protección civil en casos de emergencia o con el salvamento de la vida humana en el mar; b) aquellas que introduzcan modificaciones de disposiciones que no resulten sustanciales por su carácter meramente organizativo o procedimental, siempre que no impliquen una reducción de las medidas de protección del medio ambiente; y c) las disposiciones generales que tengan como único objeto la aprobación de planes o programas, las cuales "se ajustarán a su propia normativa específica"126.

En nuestro ordenamiento la participación pública en la elaboración de disposiciones generales se articula, fundamentalmente, a través de dos vías: (a) la participación funcional, a través de la intervención en el procedimiento de elaboración de disposiciones generales, cuyos elementos comunes se regulan ahora para todas las Administraciones públicas en la Ley 39/2015, de 1 de octubre, del Procedimiento Administrativo Común de las Administraciones Públicas; y (b) la participación orgánica, a través de la integración de ciudadanos o asociaciones en órganos administrativos, generalmente consultivos, como es el caso en materia de medio ambiente del Consejo Asesor de Medio Ambiente, regulado por el artículo 19 de la Ley 27/2006 IPPAJMA.

\subsection{La participación funcional}

El artículo 133 de la Ley 39/2015, de 1 de octubre, del Procedimiento Administrativo Común de las Administraciones Públicas (LPCAP), se adopta con vocación de establecer, por vez primera en nuestro ordenamiento, "las bases con arreglo a las cuales se ha de desenvolver la iniciativa legislativa y la potestad reglamentaria de las Administraciones Públicas con el objeto de asegurar su ejercicio de acuerdo con los principios de buena regulación, garantizar de modo adecuado la audiencia y participación de los ciudadanos en la elaboración de las normas y lograr la predictibilidad y evaluación pública del ordenamiento"127.

\footnotetext{
126 Apartado 3 del artículo 18.

127 Vid. apartado IV in fine de la exposición de motivos.
} 
En dicho artículo contempla la "participación temprana" mediante una consulta pública previa a la elaboración del proyecto normativo, a través del portal web de la Administración competente, dirigida a recabar "la opinión de los sujetos y de las organizaciones más representativas potencialmente afectados por la futura norma" sobre los problemas que aborda la norma proyectada, su necesidad $\mathrm{u}$ oportunidad, sus objetivos y las posibles alternativas ${ }^{128}$. Posteriormente, en los casos en que "la norma afecte a los derechos e intereses legítimos de las personas", el texto del proyecto o borrador de norma se publicará en el portal web correspondiente, con el objeto de dar audiencia a los ciudadanos afectados y "recabar cuantas aportaciones adicionales puedan hacerse por otras personas o entidades". Ello sin perjuicio de que pueda recabarse directamente la opinión de las organizaciones o asociaciones reconocidas por ley que agrupen o representen a las personas cuyos derechos o intereses legítimos se vean afectados por la norma y cuyos fines guarden relación directa con su objeto ${ }^{129}$. Prevé también un trámite de audiencia a los ciudadanos afectados y de información pública, que debe realizarse "de forma tal que los potenciales destinatarios de la norma y quienes realicen aportaciones sobre ella tengan la posibilidad de emitir su opinión, para lo cual deberán ponerse a su disposición los documentos necesarios, que serán claros, concisos y reunir toda la información precisa para poder pronunciarse sobre la materia"130. Finalmente, solo podrá prescindirse de los trámites de consulta, audiencia e información pública previstos en este artículo en el caso de normas presupuestarias u organizativas, o cuando concurran "razones graves de interés público que lo justifiquen"131.

Una carencia significativa en esta disposición es que no incluye expresamente la obligación de valorar las aportaciones que reciba la Administración ni de darles respuesta alguna. Y si bien la primera cabe presuponerla, la inclusión de ambas precisiones -y en particular de la segundasería más que deseable para impulsar un auténtico diálogo entre la Administración y los ciudadanos.

Por otro lado, a raíz de un recurso de inconstitucionalidad planteado por la Generalitat contra varias disposiciones de la Ley 39/2015, el Tribunal Constitucional ha declarado en su reciente Sentencia 55/2018, de 22 de mayo, que su artículo 133 invade las competencias que las comunidades autónomas tienen atribuidas estatutariamente "en orden a organizarse y regular la elaboración de sus leyes". Por lo que se refiere a la elaboración de normas de carácter

\footnotetext{
${ }^{128}$ Apartado 1.

129 Apartado 2.

130 Apartado 3.

${ }^{131}$ Apartado 4.
} 
reglamentario, la Sentencia confirma que pueden reputarse bases del régimen jurídico de las Administraciones públicas, conforme al artículo 149.1.18 CE, las previsiones del apartado 1, primer inciso ("Con carácter previo a la elaboración del proyecto o anteproyecto de ley o de reglamento, se sustanciará una consulta pública"), y 4, primer párrafo (que prevé los supuestos en que puede prescindirse de los trámites de consulta, audiencia e información públicas), y que son, por tanto, "aplicables en cuanto tales a la elaboración de reglamentos autonómicos". En relación con las demás previsiones del artículo 133, ha declarado, por el contrario, que descienden a cuestiones procedimentales de detalle, desbordando el ámbito de lo básico, y que vulneran por ello las competencias estatutarias de las comunidades autónomas en cuanto a la elaboración de sus propias disposiciones administrativas ${ }^{132}$. Los apartados declarados inconstitucionales se mantienen, no obstante, vigentes y se aplicarán solo al Estado, mientras que en las comunidades autónomas regirán las disposiciones que cada una de ellas adopte en este ámbito.

En el caso de la Administración General del Estado, las disposiciones del artículo 133 se completan, por otro lado, con las de la Ley 50/1997, de 27 de noviembre, del Gobierno, que regulan el procedimiento de elaboración de disposiciones de carácter general: el ahora artículo 26 —en la redacción dada por la Ley 40/2015, de 1 de octubre, de Régimen Jurídico del Sector Público- detalla, partiendo de los elementos comunes establecidos en el artículo 133 LPCAP, la participación en la fase de consulta, así como la audiencia y la información pública en la elaboración de normas con rango de ley y reglamentos estatales ${ }^{133}$. Estas previsiones tienen como finalidad reforzar la participación pública en la elaboración de normas generales, estableciendo con carácter preceptivo tanto la audiencia al interesado como la participación pública —salvo concurrencia de los supuestos de excepción-, de manera que su omisión o tramitación defectuosa podría acarrear la nulidad de pleno derecho de las disposiciones reglamentarias así adoptadas ${ }^{134}$.

\footnotetext{
132 FJ 7.․

133 Vid., para un análisis de la normativa anterior a la Ley 39/2015, GARCÍA GARCÍA, M. J., "La participación ciudadana en la elaboración de disposiciones reglamentarias: participación funcional e iniciativa reglamentaria", Revista catalana de dret públic, núm. 37, 2008, pp. 417-460, quien en su momento sostuvo (p. 430) que la Ley 30/1992 perdió la oportunidad de regular los trámites esenciales de los procedimientos reglamentarios, que para el Estado se concretaban en el artículo 24 de la Ley 50/1997, de 27 de noviembre, del Gobierno. Para un análisis general de las implicaciones de esta disposición, vid. ARAGUÀS GALCERÀ, I., "La participación ciudadana en la elaboración de disposiciones generales: estado de la cuestión y perspectivas de futuro tras la aprobación de la Ley 39/2015, de 1 de octubre, del Procedimiento Administrativo Común de las administraciones públicas", Revista Andaluza de Administración Pública, núm. 96, 2016, pp. 85-126.

${ }^{134}$ Vid., en este sentido, ARAGUÀS GALCERÀ, I., "La nulidad de los reglamentos por defectos en la realización de los trámites participativos", Actas del XII Congreso de la Asociación Española de Profesores de Derecho Administrativo, 2017, pp. 487-498
} 
En materia de medio ambiente, el régimen de participación es mucho más preciso y exigente, puesto que el artículo 18 de la Ley 27/2006 IPPAJMA impone a las Administraciones públicas la obligación de observar las garantías establecidas en el artículo 16 de dicha Ley, a las que ya hemos hecho referencia ${ }^{135}$. Cabe destacar aquí que el artículo 16 cubre precisamente dos de las carencias que se han puesto de relieve en relación con el artículo 133 LPCAP, puesto que en su apartado $1 . .^{\circ}$, letra c), exige expresamente que "sean debidamente tenidos en cuenta los resultados de la participación pública", y en la letra d), que una vez examinadas las observaciones y opiniones expresadas por el público, se le informará de las decisiones adoptadas y de los motivos y consideraciones en los que se basen dichas decisiones, "incluyendo la información relativa al proceso de participación pública".

\subsection{La participación orgánica}

Por lo que se refiere a la participación orgánica, el artículo 19.2 de la Ley 27/2006 IPPAJMA establece que el Consejo Asesor de Medio Ambiente (CAMA) debe informar, con carácter previo a su aprobación, todos los proyectos normativos del Estado sobre las materias ya mencionadas. EI CAMA fue creado por Real Decreto 224/1994, de 14 de febrero, y ha experimentado a lo largo de más de dos décadas diversas modificaciones en su regulación y composición. En la actualidad se configura como un "órgano colegiado que tiene por objeto la participación y el seguimiento de las políticas ambientales generales orientadas al desarrollo sostenible", que está presidido por la persona titular del Ministerio de Medio Ambiente y que reúne a representantes de diversos sectores sociales, incluyendo, claro está, a representantes de organizaciones no gubernamentales para la defensa del medio ambiente ${ }^{136}$. Siendo el CAMA el principal órgano de participación estatal en materia de medio ambiente, no es el único cauce de participación orgánica que opera en la elaboración de disposiciones generales del Estado en este ámbito; existen otros órganos colegiados creados por normas sectoriales -como el Consejo Nacional del Agua, la Comisión Nacional del Clima, el Consejo Estatal para el Patrimonio Natural y la Biodiversidad- que cuentan también con la participación de los agentes sociales y las entidades de defensa ambiental y que deben informar preceptivamente proyectos normativos en

\footnotetext{
135 Vid. apartado III.1 supra.

136 En la actualidad su composición se regula en el apartado $3 .^{\circ}$ del artículo 19 , e incluye en su seno a representantes de las cinco organizaciones no gubernamentales ambientales que se enumeran en el anexo, a representantes de las organizaciones sindicales más representativas, a dos personas en representación de las organizaciones de consumidores y usuarios, a tres personas en representación de las organizaciones agrarias más representativas de ámbito estatal y a una persona en representación de la Federación Nacional de Cofradías de Pescadores.
} 
los sectores en los que actúan. Asimismo, las comunidades autónomas, en el ejercicio de su iniciativa legislativa o potestad reglamentaria, cuentan también con órganos de participación similares $^{137}$.

La cuestión de la composición de estos órganos —que suele ser mixta, con representantes de la Administración y de grupos o asociaciones representativos de intereses económicos, sociales y medioambientales - no ha estado exenta de dificultades y de polémicas a la hora de determinar cuándo garantizan una representación adecuada y equilibrada de los "intereses ambientales" de la sociedad, siendo la más llamativa la que condujo a la declaración de nulidad de pleno derecho de las disposiciones que regulaban el Consejo Regional de Medio Ambiente de Castilla y León ${ }^{138}$, en los términos que se examinan más adelante ${ }^{139}$.

\section{ALGUNAS CUESTIONES SOBRE EL CONTROL DE SU APLICACIÓN}

La consecución de los objetivos del Convenio no solo depende de la adopción de un marco jurídico adecuado. Entran en juego, como en la mayoría de las normas ambientales, otros muchos factores, como la voluntad y los medios con los que cuenten las Administraciones para llevar a cabo de forma adecuada los procesos de participación, la calidad de la información puesta a disposición del público y las técnicas utilizadas para propiciar y facilitar su implicación de la sociedad ${ }^{140}$.

Es fundamental, además, contar con mecanismos eficientes para la supervisión y el control de su cumplimiento. A nivel interno es esencial el control judicial de la actividad de la Administración, que el Convenio de Aahrus va a reforzar también con sus disposiciones sobre acceso a la justicia. A nivel externo es igualmente importante que el Convenio cuente con instrumentos adecuados para supervisar el cumplimiento por las partes. En este caso, el Convenio, además de la clásica elaboración de informes de cumplimiento que periódicamente han de presentar los Estados, ha dispuesto un novedoso sistema de "comunicación" con el

\footnotetext{
137 Para un análisis de la participación orgánica en materia ambiental, vid. RAZQUIN LIZARRAGA y RUIZ DE APODACA ESPINOSA, Información, Participación... cit., pp. 343-354; y RUIZ DE APODACA ESPINOSA, A., "La participación orgánica en materia ambiental: el Consejo Asesor de Medio Ambiente y los consejos asesores de las Comunidades Autónomas”, Revista Jurídica de Navarra, núm. 42, 2006, pp. 93-118.

${ }^{138}$ Este consejo se creó, siguiendo el patrón del CAMA, como "el órgano colegiado de carácter consultivo de la Comunidad de Castilla y León en materia de medio ambiente, que tiene como fin servir de lugar de encuentro y participación de los sectores implicados en la elaboración, consulta y seguimiento de las políticas ambientales orientadas a promover la protección del medio ambiente y el desarrollo sostenible" (art. 2).

139 Vid. apartado IV.1 infra.

140 Vid, para un análisis de estos factores, NOGUEIRA LÓPEZ, "La participación en la evaluación..." cit., p. $142-$ 156.
} 
público, un instrumento único en el ámbito del derecho internacional ambiental que, como se examina a continuación, permite a cualquier persona denunciar vulneraciones del convenio ante un Comité de Cumplimiento ${ }^{141}$.

En consecuencia, se examina a continuación el papel que están desempeñando los tribunales -especialmente el Tribunal Supremo y los tribunales superiores de justicia de las comunidades autónomas- en la aplicación de las disposiciones sobre participación expuestas en los apartados precedentes (1) y en la aplicación de los mecanismos de control del Convenio en relación con el cumplimiento por parte de España de las disposiciones sobre participación (2).

\section{Avances en el control judicial del derecho a la "participación efectiva" en materia de medio ambiente}

Tal y como se ha analizado en los apartados precedentes, las disposiciones sobre participación a través de las que se da aplicación al segundo pilar del Convenio de Aarhus se configuran hoy día como trámites preceptivos en los procedimientos que rigen la adopción de decisiones en materia de medio ambiente, por lo que su inobservancia puede acarrear la anulación de la decisión administrativa o la declaración de nulidad de pleno derecho de las disposiciones reglamentarias o de las decisiones que se adopten prescindiendo totalmente de un trámite esencial. La participación ciudadana mediante la interposición de los recursos judiciales disponibles y la tutela judicial efectiva de los derechos de participación son esenciales para garantizar la eficacia de estas normas ambientales. Este apartado se va a limitar, sin embargo, a apuntar brevemente en qué medida la correcta aplicación de las normas sobre participación a las que hemos hecho referencia está siendo objeto de control por los tribunales, sin entrar en otras consideraciones relacionadas con el derecho de acceso a la justicia ambiental —como la de la legitimación-, que se abordan en otro trabajo de este mismo número ${ }^{142}$.

Conviene comenzar recordando la jurisprudencia desarrollada por el Tribunal Supremo en relación con la obligación de las autoridades públicas de tomar en la debida consideración las alegaciones de las partes interesadas y las aportaciones del público en los trámites de

\footnotetext{
${ }^{141}$ Para un análisis general de estos mecanismos, vid. PIGRAU SOLÉ, A. y BORRÁS PENTINAT, S., "Diez años del Convenio de Aahrus sobre el acceso a la información, la participación y el acceso a la justicia en materia de medio ambiente", Pigrau Solé (dir.), Acceso a la información... cit., pp. 47-73.

142 Vid. RUIZ DE APODACA ESPINOSA, A. M., "El acceso a la justicia ambiental a nivel comunitario y en España veinte años después del Convenio de Aarhus", Revista Catalana de Dret Ambiental, Vol. IX, Núm. 1, Junio, 2018. Sobre la tutela judicial en materia de medio ambiente, vid. también PEÑALVER I CABRÉ, A., "Nuevos instrumentos para la aplicación de la legislación ambiental ante la inactividad administrativa: de las acciones ciudadanas (citizen suits) al Convenio de Aarhus", Revista de Administración Pública, 172, 2007, pp. 474-475; y del mismo autor, La defensa de los intereses colectivos en el contencioso-administrativo, Thomson-Aranzadi, Cizur Menor, 2016.
} 
participación. En una serie de casos sobre la aplicación del artículo 6 de la antigua Ley 4/1989, de 27 de marzo, de Conservación de los Espacios Naturales y de la Flora y Fauna Silvestres que establecía trámites de consulta e información pública en la elaboración de los planes de ordenación de recursos naturales-, el Tribunal Supremo, partiendo del carácter esencial de la participación en estos procesos de planificación, precisó lo siguiente:

El exacto cumplimiento de tales trámites exige no solo la mera formulación y recepción de los diversos alegatos de esas entidades y particulares, sino la reposada lectura de los mismos por la Administración y su contestación específica sobre las razones que lleven a la aceptación o rechazo de tales alegaciones, para así considerar integrado y realizado el trámite de audiencia pública, que debe posibilitar la corrección de errores, puntos de vista o cambios de enfoque en el contenido del Plan ${ }^{143}$.

Esta doctrina exige, en definitiva, que las Administraciones analicen las aportaciones hechas por el público y las personas interesadas a través de estos mecanismos e informen sobre los resultados del proceso de la participación, en línea con las exigencias que el Convenio de Aarhus establece en su artículo 7 en conexión con el artículo 6.8 y con la normativa básica adoptada en su aplicación, a la que se ha hecho referencia en el apartado precedente.

Tal y como se ha apuntado en apartados precedentes ${ }^{144}$, un supuesto en el que la participación real y efectiva del público se puede ver comprometida es el de la introducción de modificaciones sustanciales en un plan o proyecto con posterioridad a los trámites de participación pública; la Sentencia del Tribunal Superior de Justicia de Asturias, de 6 de julio de 2015, sobre el Plan Estratégico de Residuos del Principado de Asturias, declaró que en estos casos es preceptivo informar de nuevo a los ciudadanos a fin de posibilitar que formulen las alegaciones oportunas. El Tribunal consideró esta infracción como un supuesto de anulabilidad "por la omisión de un requisito esencial para alcanzar su fin", retrotrayendo las actuaciones para que con carácter previo a su aprobación se procediera al trámite de información pública ${ }^{145}$.

Por lo que se refiere a los proyectos, planes o programas sometidos a evaluación ambiental, los tribunales no solo declaran nulas de pleno derecho las autorizaciones de proyectos o la

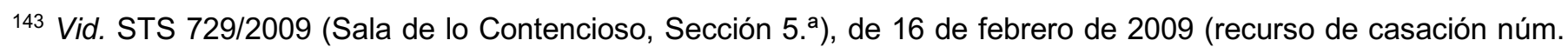
9505/45: Plan de Ordenación de los Recursos Naturales del Espacio Natural Arribes del Duero), con cita de las SSTS de la misma Sala de 25 de febrero de 2003 (recurso de casación 6876/1999) y de 4 de marzo de 2003 (recurso de casación 5954/1999).

${ }^{144} \mathrm{Vid}$., al respecto, los apartados 2 y 3 del epígrafe III.

145 Para un análisis de esta sentencia, vid. ALENZA GARCÍA, J. F., "La participación en la planificación de residuos", Revista Aranzadi de Derecho Ambiental, núm. 36, 2017.
} 
adopción de planes por ausencia absoluta de este trámite esencial ${ }^{146}$, sino que también están entrando a controlar si la evaluación, cuando tiene lugar, incurre en algún defecto o vicio relevante en su tramitación, como lo es, sin duda, la vulneración de las disposiciones sobre participación ${ }^{147}$. Del mismo modo, la infracción de las disposiciones sobre participación está siendo tomada en consideración para declarar la nulidad de autorizaciones ambientales integradas otorgadas en el marco de la Ley de Prevención y Control Integrados de la Contaminación y de las normas autonómicas que la desarrollan o complementan ${ }^{148}$.

Más recientemente, el Tribunal Supremo ha reconocido a una organización ambiental (Fundación Oceana) el derecho de participación en el marco de un procedimiento administrativo sancionador, siempre que cumpla los requisitos que la cualifican como actora interesada establecidos en el artículo 23 LEA $^{149}$. En este caso, la Dirección General de la Marina Mercante negó legitimación a dicha ONG para ser parte en procedimiento sancionador promovido contra dos buques por infracción consistente en el vertido de hidrocarburos al medio marino. La Sentencia del Tribunal Superior de Justicia de Madrid que desestimó su recurso ${ }^{150}$ fue casada por el Tribunal Supremo, que ha abierto así todo un nuevo campo en el derecho de participación de las organizaciones no gubernamentales en relación con la efectiva aplicación de las disposiciones sancionadoras en materia de medio ambiente, el cual implica que se les reconozca la legitimación para ser parte en un procedimiento sancionador al ejercer la acción popular en asuntos medioambientales $y$, en consecuencia, que se les notifiquen los actos producidos en el procedimiento sancionador y se les permita formular alegaciones y participar en la instrucción de este ${ }^{151}$. Si bien el Tribunal Supremo parte en su Sentencia de un exhaustivo examen de las disposiciones del Convenio de Aarhus y de las directivas de la Unión Europea, en el desarrollo de esta doctrina se da un paso más allá de lo estrictamente exigido por el

\footnotetext{
146 Vid. la STS de 27 de noviembre de 2013 (recurso de casación 4123/2019), falta del trámite esencial de la evaluación ambiental de proyecto infraestructura viaria; en el ámbito de la planificación, vid. por ejemplo, la STS 4967/2015, de 11 de noviembre de 2015 (recurso de casación 1814/2014), que anula el Plan de Ordenación Municipal de Vigo por haberse omitido el trámite de evaluación ambiental estratégica, y que trae causa del recurso contencioso-administrativo interpuesto por una asociación de vecinos.

147 Vid., por ejemplo, la STS de 27 de noviembre de 2013 (recurso de casación 4123/2010), en la que el Tribunal Supremo desestimó el recurso interpuesto por el Gobierno de Canarias contra la Sentencia de la Sala de lo Contencioso-Administrativo del Tribunal Superior de Justicia de Canarias, de 15 de enero de 2010, que anuló un proyecto de carretera regional por no respetarse los trámites adecuados de participación e información al público.

148 Vid. Sentencia del Tribunal Superior de Justicia de la Comunidad Valenciana (Sala de lo ContenciosoAdministrativo, Sección $1 .^{\mathrm{a}}$ ), recurso núm. 954/2015, de 9 de enero de 2015, en la que se declara nula, a instancias del Ayuntamiento de Alcora y de la Plataforma Ciutadana No a la Contaminación, la autorización ambiental integrada para la instalación de almacenamiento y tratamiento de residuos peligrosos y no peligrosos.

149 STS (Sala de lo Contencioso-Administrativo, Sección 3. ${ }^{a}$ ) de 7 de julio de 2017 (recurso de casación núm. 1783/2015).

${ }^{150}$ Sentencia del Tribunal Superior de Justicia de Madrid (Sala de lo Contencioso-Administrativo, Sección 10. ${ }^{a}$ ), recurso núm. 816/2013, de 18 de marzo de 2015.
}

151 FJ $7 .{ }^{\circ}$. 
Convenio, ya que la obligación que este impone a las partes se limita, en principio, a la participación "cuando se trate de autorizar o no" las actividades específicas reguladas en el artículo 6 (apartado 1).

También recientemente se ha dictado una innovadora sentencia —en este caso, por el Tribunal Superior de Justicia de Castilla y León-que controla la adecuación de los mecanismos de participación orgánica en materia de medio ambiente a las disposiciones sobre participación de la Ley 27/2006 IPPAJMA. Dicho Tribunal estimó el recurso interpuesto por la Federación Ecologistas en Acción de Castilla y León contra el Decreto 1/2017, de 12 de enero, por el que se crea y regula el Consejo Regional de Medio Ambiente de Castilla y León ${ }^{152}$, y, en particular, contra las disposiciones que regulaban su composición ${ }^{153}$, por considerar que vulneraban el derecho de participación en los términos reconocidos en los artículos 19.3, 1 b) y 3.2.a) de la Ley 27/2006 IPPAJMA. La principal alegación formulada por esta asociación era que el susodicho Consejo estaba constituido mayoritariamente por representantes de la Administración, siendo muy reducido el número de vocales de las organizaciones representativas de intereses sociales $y$, en especial, el de las organizaciones no gubernamentales ambientales ${ }^{154}$. El Tribunal Superior de Justicia de Castilla y León estimó el recurso al apreciar que "el derecho a la participación ciudadana en materia medioambiental, que es la base fundamental de la demanda, tiene un sólido respaldo normativo y no se limita a ser un simple principio general para la interpretación de los textos normativos sino un derecho que debe garantizarse y por lo tanto ha de disponerse de los medios adecuados para que el mismo sea real y efectivo y no meramente nominal".

Y concluyó que, a la luz del objeto del Comité y de su composición, no había "una proporcionalidad entre la representación de unos sectores y otros" y que "el derecho de participación que debe respetar el Decreto 1/2017 no solo se ve afectado negativamente desde un punto de vista cuantitativo sino también cualitativo"155.

\footnotetext{
152 Este consejo se creó, siguiendo el patrón del CAMA, como "el órgano colegiado de carácter consultivo de la Comunidad de Castilla y León en materia de medio ambiente, que tiene como fin servir de lugar de encuentro y participación de los sectores implicados en la elaboración, consulta y seguimiento de las políticas ambientales orientadas a promover la protección del medio ambiente y el desarrollo sostenible" (art. 2).

${ }^{153}$ Artículos 5 a 8.

$154 \mathrm{De}$ los cincuenta y un miembros con derecho a voto, treinta y tres eran cargos de las distintas Administraciones, y la Administración proponía también cuatro representantes de la comunidad científica y técnica; los dieciocho restantes se repartían entre los representantes de diversos intereses económicos, sociales y ambientales, siendo solo dos las organizaciones ambientales miembros de dicho Consejo.

155 Sentencia del Tribunal Superior de Justicia de Castilla y León núm. 4095/2017, de 20 de diciembre de 2017.
} 
Finalmente, y en relación con la obligación de establecer "plazos razonables" para posibilitar que el público se informe, se prepare y participe efectivamente en el proceso de toma de decisiones (conforme a las obligaciones previstas en los artículos 6.3 y 7 del Convenio de Aarhus), existe ya alguna resolución judicial en la que tal cuestión ha sido objeto de consideración, si bien sin llegar a apreciarse el incumplimiento de esta obligación ${ }^{156}$. Ciertamente la apreciación por los tribunales de un incumplimiento de estas disposiciones del Convenio no parece en principio muy probable, en particular porque las obligaciones que establece el Convenio en estas giran en torno al concepto indeterminado de "plazo razonable". No obstante, no cabe descartar la posibilidad de dicho control incluso en los casos en que las Administraciones hayan respetado estrictamente los plazos establecidos por la normativa aplicable. En primer lugar porque, conforme a la doctrina constitucional, "la supuesta contradicción de los tratados por las leyes o por otras disposiciones normativas posteriores no es cuestión que afecte a la constitucionalidad de éstas, y que, por tanto, deba ser resuelto por el Tribunal Constitucional", sino que, "como puro problema de selección del Derecho aplicable al caso concreto, debe ser resuelto por los órganos judiciales en los litigios de que conozcan"157; en segundo lugar porque el concepto indeterminado "plazo razonable" está siendo objeto de precisión por el Comité de Cumplimiento del Convenio de Aarhus, de modo que, a la hora de determinar si el plazo estipulado es o no "razonable", los tribunales nacionales han de tomar en consideración la interpretación que de esta obligación está haciendo dicho Comité en sus informes y recomendaciones, así como las decisiones de las conferencias de las partes que respaldan dichos informes, en los términos que se analizan en el siguiente apartado ${ }^{158}$.

En definitiva, las autorizaciones y los planes o programas en materia de medio ambiente que eludan los trámites de participación preceptivos —en los términos de las disposiciones ya examinadas- pueden ser declarados nulos de pleno derecho [en el caso de las autorizaciones, conforme al artículo 47.1.e) LPAC por prescindir de trámites esenciales; $y$, en el caso de planes o programas que se aprueben mediante disposiciones de carácter general, conforme al artículo 47.2 LPAC]. Asimismo, conforme al artículo 48 LPAC, las autorizaciones de actividades con

\footnotetext{
156 Vid., por ejemplo, la Sentencia núm. 42/2013 del Tribunal Superior de Justicia de Navarra, de 10 de enero de 2013 (recurso núm. 211/2011), en la que se declara nulo el Plan Integrado de Gestión de Residuos de Navarra por adolecer de ciertos defectos procedimentales en la formulación de la declaración de incidencia ambiental y, fundamentalmente, por no contener información sobre los lugares e instalaciones apropiados para la eliminación de los residuos (Sentencia que fue confirmada por la STS de 16 de enero de 2015, recurso de casación 711/2013). En este caso, el TSJ de Navarra desestimó las alegaciones relativas a la vulneración de las disposiciones sobre participación al considerar que sí se había posibilitado al público participar en la elaboración del Plan "en plazos razonables e idóneos".

${ }_{157}$ Vid., por todas, la STC 2007/2013, de 5 de diciembre, FJ 4. ${ }^{\circ}$, y las allí citadas.

158 Vid. p. 55.
} 
incidencia en el medio ambiente que estén dentro del ámbito de aplicación del Convenio de Aarhus pueden ser también anuladas por los tribunales cuando incurran en cualquier infracción de las garantías sobre participación establecidas en este o en las normas internas por las que se aplica.

El desarrollo y la consolidación de jurisprudencia mediante la aplicación de estas disposiciones -que en algunos aspectos, como el del derecho de participación de ONG en procedimientos sancionadores, podría evolucionar hacia posiciones más exigentes que las del Convenio de Aarhus- es fundamental para garantizar una participación "real y efectiva" del público en materia de medio ambiente.

\section{Los mecanismos de control del Convenio}

\subsection{Los informes de seguimiento: los avances y obstáculos de los que dan cuenta}

El artículo 10 del Convenio establece lo siguiente: "En sus reuniones, las Partes seguirán permanentemente la aplicación del presente Convenio sobre la base de los informes comunicados regularmente por las Partes". Dichos informes han de comprender información puntual sobre las medidas legislativas, reglamentarias y otras medidas adoptadas para cumplir el Convenio, así como sobre los obstáculos encontrados en su ejecución ${ }^{159}$.

Los informes de cumplimiento presentados por España hasta la fecha ${ }^{160}$ han sido elaborados por el ministerio competente en materia de medio ambiente en colaboración con otros órganos de la Administración del Estado y de las Administraciones autonómica y local (a través de la Federación Española de Municipios y Provincias). Se ha contado, asimismo, con la participación del Consejo Asesor de Medio Ambiente (CAMA), así como de otros representantes de la sociedad civil, y se ha puesto a disposición del público la información sobre su elaboración a través de la página web del ministerio, siguiéndose así un proceso abierto a la participación del

\footnotetext{
159 Vid, Decisión I/8, la Conferencia de las Partes (Lucca, Italia, octubre 2002), posteriormente desarrollado mediante Decisión II/10 de la Conferencia de las Partes.

160 Desde la ratificación del Convenio, España ha presentado cuatro informes de cumplimiento del Convenio, presentados en las sesiones de las reuniones de las partes celebradas en 2008 (Riga), 2010 (Ginebra), 2013 $\begin{array}{lllllll}\text { (Maastricht) y } 2017 & \text { (Montenegro). } & \text { Disponibles } & \text { todos } & \text { ellos } & \text { en }\end{array}$ <http://www.mapama.gob.es/es/ministerio/servicios/informacion/informacion-ambiental/informes-nacionales-decumplimiento/default.aspx> [última consulta, 28 de abril de 2018].
} 
público, en coherencia con el Convenio, a través de alegaciones a los borradores de dichos informes ${ }^{161}$.

En dichos informes el Estado español ha dado cuenta de la evolución de las diversas normas adoptadas para cumplir formalmente las disposiciones del segundo pilar del Convenio (prestando especial atención a la normativa básica). Incluyen, asimismo, información sobre otras medidas de implementación, como las prácticas administrativas relacionadas con el uso de las nuevas tecnologías para facilitar la transparencia y la participación temprana (destacando en particular la publicación, en las páginas web de los órganos ambientales, fundamentalmente estatal y autonómicos, de información sobre los distintos procesos de participación seguidos) ${ }^{162}$. Así, por ejemplo, el último informe presentado a la reunión de las partes en 2017 (y fechado el 28 de noviembre de 2016) pone de relieve, como novedad, que las Administraciones también están recurriendo a las redes sociales, al haberse convertido en uno de los principales medios de comunicación en la sociedad actual. A tales efectos, han creado sus propios perfiles para la difusión de información y, como vía adicional de comunicación con el público en procedimientos ambientales, incluso han articulado sus propias redes sociales ${ }^{163}$.

Destacan por fundamentales, por otro lado, las medidas de educación y sensibilización que las Administraciones públicas llevan a cabo a través de distintos medios, como ayudas, becas y subvenciones destinadas a fomentar la educación y concienciación respecto a los problemas medioambientales. Sin embargo, el último informe de cumplimiento presentado a la reunión de las partes reconoce que "las limitaciones presupuestarias han supuesto en ocasiones una disminución de este tipo de iniciativas" ${ }^{164}$.

Por lo que se refiere a los principales obstáculos encontrados en la aplicación del Convenio, el informe de 2017 pone de manifiesto que, con carácter general, "se detectan aún ciertas carencias, pese al notable esfuerzo realizado, fundamentalmente en el ámbito organizativo de

\footnotetext{
161 Según se da cuenta en dichos informes; vid., por ejemplo, el Informe de Cumplimiento de España 2017 (fechado el 28.11.2016), p. 2, en <http://www.mapama.gob.es/es/ministerio/servicios/informacion/informacionambiental/informes-nacionales-de-cumplimiento/default.aspx> [última consulta, 28 de abril de 2018].

${ }_{162}$ Así, por ejemplo, dentro del procedimiento de evaluación ambiental, tanto de planes y programas como de proyectos, la Administración General del Estado pone a disposición del público la documentación ambiental y facilita información sobre la tramitación telemática de los expedientes a través de la página web del ministerio responsable en materia de medio ambiente. A tales efectos, se ha desarrollado el proyecto SABIA, que tiene por objeto mejorar la gestión de las evaluaciones ambientales, así como la consulta por el público interesado, aglutinando las bases de datos de los expedientes en procedimiento de evaluación ambiental, que ha incorporado su georreferenciación y ha creado una interfaz para la teletramitación. Vid. Informe de Cumplimiento de España 2017, p. 28, apartado 111.

163 Ibid. p. 28, apartados 130-131.

${ }^{164} \mathrm{Ibid}$. p. 6, apartado 16.
} 
las distintas Administraciones”165. En relación con la información y participación a través de las redes sociales, señala, en particular, que "los recursos humanos necesarios para tal objetivo suponen una importante dificultad, aunque en los últimos años se ha producido una progresiva generalización de este medio de comunicación con el ciudadano"166.

En cuanto a los problemas experimentados en la aplicación de los tres artículos sobre participación del Convenio, el informe identifica los siguientes:

i) Se constata que la aplicación de las disposiciones del artículo 6 (participación en las decisiones relativas a actividades específicas) plantea especiales dificultades en el caso de los entes locales, debido a "la falta de conocimiento en detalle de sus disposiciones, y la falta de interés en el mismo por parte de una fracción considerable de la ciudadanía [sic]"167. Y también señala que "el plazo mínimo regulado en las legislaciones sectoriales para presentar alegaciones en los procedimientos sujetos a intervención ambiental, especialmente en las EIA y AAI resulta, a juicio de algunos ciudadanos e interlocutores sociales, insuficiente, dado lo voluminoso de los expedientes y su complejidad técnica" ${ }^{168}$. Cuestión esta que, como veremos a continuación, ha dado lugar a la tramitación de dos comunicaciones por parte de ONG al Comité de Cumplimiento del Convenio.

ii) En relación con el artículo 7 del Convenio (participación en los procedimientos de planificación), se constata también que existen "problemas de escasa participación". Además, el informe recoge alegaciones en las que se reitera que "los plazos de participación son insuficientes debido al volumen o complejidad de la información asociada al proyecto o actividad"169.

iii) En cuando a la implementación del artículo 8 (participación en la elaboración de disposiciones reglamentarias), destaca igualmente la escasa participación pública pese a "diversas campañas de sensibilización medioambiental promovidas por las distintas Administraciones y ONG", por lo que considera conveniente seguir promoviendo "un mejor conocimiento sobre los derechos de acceso a la información, de participación pública y de acceso a la justicia en materia de medio ambiente, de forma especial en el ámbito de las Administraciones Locales, dada su proximidad a los ciudadanos".

\footnotetext{
165 Informe de Cumplimiento 2017, p. 8, apartado 28.

166 Ibid., apartado 29.

167 Ibid., p. 26, apartado 118.

168 Ibid., p. 26, apartado 119.

169 Ibid., p. 28. Apartado 128.
} 
En relación con la presentación de los informes de cumplimiento, hay que destacar que, a diferencia de lo acaecido en relación con otras partes del Convenio, no se ha presentado hasta el momento ningún informe sobre la aplicación del Convenio en España realizado exclusivamente por ONG (los denominados en el argot de las organizaciones internacionales "informes en la sombra"), cuyos informes aportan otra visión, generalmente más crítica que la oficial, sobre la situación en un determinado país ${ }^{170}$, si bien este hecho se ve en parte compensado por el mecanismo de comunicaciones que se examina en el siguiente epígrafe.

Finalmente, es preciso también llamar la atención sobre el hecho de que no existe todavía ningún instrumento que permita realizar un seguimiento o aproximación global a la aplicación de las disposiciones del Convenio que facilite algún indicador que permita medir en qué grado se avanza (o si se avanza) hacia una "participación real y efectiva" de los ciudadanos en la toma de decisiones en materia de medio ambiente. Ello, a diferencia de lo que ocurre respecto a las disposiciones sobre acceso a la información, puesto que, en este caso, se publican al menos informes estadísticos anuales sobre el número de solicitudes tramitadas (conforme a la disposición adicional octava de la Ley 27/2006 IPPAJMA) ${ }^{171}$, y en los informes de cumplimiento se da cuenta de los datos recogidos (y de la situación que reflejan).

\subsection{España ante el Comité de Cumplimiento del Convenio de Aarhus}

El Convenio de Aarhus establece, en su artículo 15, un innovador mecanismo para el control del cumplimiento de las obligaciones asumidas por las partes. Según esta disposición:

La Reunión de las Partes adoptará por consenso mecanismos facultativos de carácter no conflictivo, no judicial y consultivo para examinar el cumplimiento de las disposiciones del presente Convenio. Esos mecanismos permitirán una participación apropiada del público y podrán prever la posibilidad de examinar comunicaciones de miembros del público respecto de cuestiones que guarden relación con el presente Convenio.

En la primera reunión, celebrada en Lucca en 2002, se adoptó la Decisión 1/7, sobre seguimiento de cumplimiento, que regula la composición y el funcionamiento del Comité de

\footnotetext{
170 La lista de los "informes en la sombra" presentados en relación con el cumplimiento de otros países puede consultarse en <http://www.unece.org/env/pp/reports organisations 2017.html> [última consulta, 28 de abril de 2018].

171 Disponibles en <http://www.mapama.gob.es/es/ministerio/servicios/informacion/informacion-ambiental/informesestadisticos/> [última consulta, 28 de abril de 2018].
} 
Cumplimiento del Convenio ${ }^{172}$. Entre las funciones que se le han encomendado destacan las siguientes: examinar cualquier petición o comunicación que le sea sometida por particulares; preparar informes de cumplimiento de las disposiciones del Convenio a petición de la Conferencia de las Partes; y hacer seguimiento, evaluar y facilitar el cumplimiento a través de los informes de aplicación que elaboran las partes conforme a su artículo $10.2^{173}$.

De entre estas funciones, el mecanismo de comunicación (o denuncia) por particulares u organizaciones ambientales sobre incumplimiento de las disposiciones del Convenio ha supuesto una importante novedad en el ámbito del derecho internacional para la protección del medio ambiente. Dicho mecanismo, regulado también en la Decisión $1 / 7$, se articula a través de un procedimiento basado en los principios de contradicción (entre el comunicante y el Estado afectado) y transparencia (todas las comunicaciones y la subsiguiente documentación a la que dan lugar se publican en la página web del Convenio) ${ }^{174}$. El Comité debe considerar todas las comunicaciones que reciba, a menos que incurran en uno de los supuestos de inadmisibilidad establecidos en la Decisión 1/7: (a) que sean anónimas; (b) que incurran en abuso de derecho; (c) que sean manifiestamente irrazonables; o (d) que sean incompatibles con la propia Decisión $1 / 7$ o con el Convenio ${ }^{175}$. Además, debe tener en consideración si se ha hecho uso de los recursos nacionales disponibles, salvo que la tramitación sea "irrazonablemente larga o sea obvio que no se facilita un remedio suficiente y efectivo"176. El Comité ha interpretado esta última disposición de la Decisión de forma flexible, en el sentido de que no implica un requisito estricto de agotar todas las vías de recurso internas antes de acudir al Comité, de manera que puede considerar casos incluso allí donde la resolución de un recurso no resulte irrazonablemente prolongada. Ello sin perjuicio de que, si un comunicante no ha hecho uso alguno de los mecanismos internos de recurso, el Comité puede declarar que el asunto debe ser abordado a través de los procedimientos de control nacional y no por el mecanismo de cumplimiento del Convenio ${ }^{177}$.

\footnotetext{
172 ECE, Decision I/7 on Review of Compliance, Addendum, Report of the First meeting of the parties (Lucca, 21-23 de octubre de 2002), ECE/MP.PP/2/Add.8, <http://www.unece.org/env/pp/ccbackground.html> [última consulta, 28 de abril de 2017].

173 Vid., sobre el ejercicio de estas funciones, UNECE, Guidance Document on the Aarhus Convention Compliance Mechanism, <http://www.unece.org/fileadmin/DAM/env/pp/compliance/CC GuidanceDocument.pdf> [última consulta, 28 de abril de 2018].

174 Disponibles en la página web del Convenio <http://www.unece.org/env/pp/pubcom.html> [última consulta, 28 de abril de 2018].

175 Párrafo 20 del anexo de la Decisión 1/7.

176 Párrafo 21 del anexo de la Decisión 1/7.

177 Vid., por ejemplo, Compliance Committee, Preliminary determination of admissibility of communication to the Aarhus Convention Compliance Committee concerning compliance by Spain with the provisions of the Convention on public participation in connection with updating of environmental permits, p. 1,
} 
Tras el examen de las comunicaciones admitidas a trámite, el Comité emite un informe en el que declara si aprecia o no los incumplimientos denunciados, y en el que se incluyen recomendaciones para ponerles fin dirigidas directamente al Estado en cuestión o a la reunión de las partes, que, en su caso, las asume a través de decisiones.

Este sistema de comunicaciones o denuncias de los particulares ha sido, junto a los informes periódicos sobre la aplicación del Convenio que presentan los Estados a las reuniones de las partes, el instrumento de control más utilizado hasta el momento ${ }^{178}$ y supone un importante complemento (y contrapunto) a los informes oficiales de aplicación elaborados por los propios Estados.

Hasta el momento, el Comité ha recibido y tramitado un total de 157 comunicaciones, la mayoría presentadas por organizaciones no gubernamentales de defensa del medio ambiente. De ellas, nueve se refieren a incumplimientos por España protagonizados por distintas Administraciones (entes locales, comunidades autónomas o Estado). Tres comunicaciones han sido ya resueltas (ACCC/C/2008/24, ACCC/C/2009/36 y ACCC/C/2014/99), dos están pendientes de resolución (ACCCC/C/2014/122 y ACCC/C2017/153) y cuatro fueron declaradas inadmisibles por no reunir los requisitos establecidos en la Decisión 1/7 (las comunicaciones $A C C C / C / 2008 / 34$, ACCC/C/2012/78, ACCC/C/2014/103 y ACCC/C/2017/152).

Se examinan a continuación las comunicaciones relacionadas con la aplicación en España de las disposiciones sobre participación pública sobre las que se ha pronunciado el Comité, así como la Comunicación ACCC/2014/122, aún pendiente de resolución, pero de la que ya está disponible la respuesta del Gobierno de España ${ }^{179}$.

i. Las comunicaciones ACCC/C/2008/24 y ACCC/C/2009/36 y la obligación de establecer "plazos razonables" de participación

En estas dos comunicaciones se alegaron diversas vulneraciones del Convenio, siendo de especial interés por lo que respecta a este trabajo las quejas relativas al incumplimiento de la obligación de establecer "plazos razonables" para la participación en los procedimientos objeto del Convenio.

$<$ http://www.unece.org/fileadmin/DAM/env/pp/compliance/C2015-

122_Spain/Preliminary_Determination_on_admissibility_C122_Spain.pdf (ACCC/C/2014/122)> [última consulta, 28 de abril de 2018].

${ }_{178}$ De hecho, otros mecanismos como la queja o denuncia entre partes permanecen inéditos.

179 Todas ellas disponibles en <http://www.unece.org/env/pp/cc/com.html> [última consulta, 28 de abril de 2018]. 
La Comunicación ACCC/C/2008/24 fue presentada el 13 de mayo de 2008 por la Asociación para la Justicia Ambiental, que denunciaba -además de diversas vulneraciones de las disposiciones sobre acceso a la información y a la justicia- el incumplimiento por el Ayuntamiento de Murcia de los apartados 1, 2, 4 y 6 del artículo 6 del Convenio durante la tramitación de un proyecto de urbanización de zona residencial llevada a cabo en un terreno sujeto a un régimen especial de protección, previa modificación del Plan General de Ordenación Urbana de Murcia. La Asociación alegaba que no se le dio oportunidad de participar de forma efectiva ni en la modificación del Plan General que reclasificaba el terreno como residencial, ni en el Plan Parcial ni en la aprobación del proyecto de desarrollo urbanístico.

En este caso, además de las repuestas del Ayuntamiento que informaban sobre los trámites de información pública realizados, también medió una comunicación del Ministerio de Medio Ambiente, y Medio Rural y Marino en la que se puso de manifiesto que era "consciente" de que "en determinadas ocasiones, el plazo mínimo ofrecido para participar en procedimientos relacionados con el medio ambiente, puede resultar insuficiente, dado lo voluminoso de los expedientes y su complejidad técnica". Y dicha comunicación también destacaba ante el Comité la importancia de "concienciar a las autoridades públicas del cumplimiento de sus obligaciones respecto al Convenio de Aarhus y normativa derivada" mediante las actividades de formación y difusión que llevaba a cabo el Ministerio y de las que daba cuenta al Comitéé180.

Finalmente, el Comité de Cumplimiento declaró que, en el caso del Proyecto de Urbanización, España incumplió los requisitos establecidos en el artículo 6.3 (establecimiento de "plazos razonables"), dado que las autoridades locales fijaron un plazo de veinte días naturales para que el público examinara la abundante documentación sobre el proyecto e hiciera alegaciones, plazo que coincidió además con el período vacacional de Navidad. Entre las recomendaciones que recoge el informe para resolver los incumplimientos evidenciados por esta comunicación, el Comité incluyó dos relacionadas con la participación pública: (i) establecer exigencias claras para que las autoridades públicas cumplan con la obligación de informar sobre los procesos de toma de decisión de forma adecuada, puntual y efectiva, e informarlas de que adoptar acuerdos o actuaciones que reduzcan las opciones y soluciones posibles antes de dar participación al público es contrario al artículo 6 del Convenio; y (ii) establecer en los procedimientos de participación pública "plazos razonables" en las diferentes fases que den tiempo suficiente al público para que se prepare y participe efectivamente, "teniendo en cuenta que los períodos

180 Comunicación del Ministerio de Medio Ambiente de 8 de febrero de 2011, disponible en http://www.unece.org/env/pp/compliance/Compliancecommittee/24TableSpain.html [última consulta, 28 de abril de 2018]. 
vacacionales dentro de dichos plazos impiden la participación efectiva del público". Asimismo, recomendaba que, "dada la complejidad y la necesidad de consulta con expertos, la legislación del suelo debe ser revisada para ampliar el plazo existente de 20 días, a la luz de los hallazgos y conclusiones del Comité"181.

Por lo que se refiere a la Comunicación ACCC/C/2009/36, la Plataforma Contra la Contaminación de Almendralejo (Badajoz) presentó el 2 de marzo de 2009 un escrito que denunciaba diversos incumplimientos del Convenio tanto por la Administración local como por la autonómica y la estatal. En relación con el derecho de participación, la Plataforma alegaba en concreto que no pudo tener una participación real y efectiva en los procedimientos sobre instalación de tres centrales térmicas de ciclo combinado y una refinería de petróleo en Extremadura, todos ellos sometidos a la Ley 16/2002, de 1 de julio, de prevención y control integrados de la contaminación (en adelante, Ley 16/2002 IPPC). En relación con el proyecto para instalar la refinería, argumentaba, en particular, que el plazo para la consulta pública (treinta días, según la Ley IPPC) era insuficiente y que no se había facilitado un acceso adecuado a la información, pues el estudio de impacto ambiental no estaba disponible y se les exigió personarse físicamente en las dependencias de la Dirección General correspondiente durante el horario laboral, donde se les prohibió hacer copias en formato digital y solo pudieron examinar el proyecto, "de miles de páginas", a través de tres ordenadores (uno fuera de funcionamiento). En la respuesta del Estado se puso de manifiesto que estaba en curso la evaluación ambiental de la refinería y que se habían llevado a cabo ya diversos trámites de información pública. Tras referirse a la normativa aplicable, el Estado alegó que la Administración estaba fomentando la participación temprana mediante la puesta a disposición del público de la información a través de las páginas web oficiales, lo que notificaba a asociaciones, organizaciones y otras partes interesadas. En el caso del proyecto de la refinería, por ejemplo, destacó que un resumen y el documento de síntesis del estudio de impacto ambiental se habían hecho públicos a través de internet ${ }^{182}$.

\footnotetext{
181 Vid. UNECE, Report of the Compliance Committee on its Twenty-sixth meeting, Addendum - Findings and recommendations with regard to Communication ACCC/C/2008/24 concerning compliance by Spain, ECE/MP.PP/C.1/2009/8/Add.1., p. <http://www.unece.org/env/pp/compliance/Compliancecommittee/24TableSpain.html> [última consulta, 28 de abril de 2018].

182 Vid. UNECE, Report of the Compliance Committee on its Twenty-eight meeting, Addendum -Findings and recommendations with regard to communication ACCC/C/2009/36 concerning compliance by Spain, 18 de junio de 2010, ECE/MP.PP/C.1/2010/4/Adds.2, <http://www.unece.org/env/pp/compliance/Compliancecommittee/36TableSpain.html> [última consulta, 28 de abril de 2018].
} 
El Comité de Cumplimiento declaró, sin embargo, que se había incumplido el artículo 6.6 (derecho a "consultar cuando lo pida y cuando el derecho lo exija, de forma gratuita, en cuanto estén disponibles todas las informaciones que ofrezcan interés para la toma de decisiones") en conexión con el artículo 4.1.b) (derecho a recibir la información en la forma solicitada), puesto que las autoridades no permitieron hacer copias de la información puesta a disposición del público in situ, información que era, por otro lado, más extensa que la que se podía encontrar en los resúmenes y documentos de síntesis puestos a disposición del público en la red ${ }^{183}$. Asimismo, declaró que se vulneró también el apartado 3 del artículo 6 (obligación de establecer "plazos razonables" para la participación) dadas las circunstancias del caso. En concreto, el Comité declaró que la participación pública en la toma de decisiones sobre determinados proyectos se dificulta cuando las autoridades públicas establecen condiciones como las impuestas en el caso del proyecto de refinería (que exigía al público desplazamientos entre 30 y 200 kilómetros para acceder a miles de páginas a través únicamente de dos ordenadores, y sin permitir hacer copias en CD-ROM o DVD, por lo que había que examinar toda la documentación in situ en un plazo de un mes). Finalmente, el Comité reiteró la primera de las recomendaciones planteadas en materia de participación, en relación con el cumplimiento de los apartados 3 y 4 del artículo 6 del Convenio, en su informe anterior sobre el asunto ACCC/C/2008/24.

Ambos casos han sido objeto de seguimiento sistemático por el Comité, que emitió un informe sobre el estado de cumplimiento de las recomendaciones a la cuarta reunión de las partes, celebrada en 2011, en el que señalaba que no todas habían sido seguidas por las autoridades españolas (entre otras, la de ampliar el plazo de veinte días establecido en la normativa del suelo de Murcia) y reiteraba su recomendación de establecer "plazos adecuados" para los procesos de participación pública "de tal manera que se excluyan los periodos vacacionales y se permita una amplia participación"184. Como consecuencia de este, la cuarta reunión de las partes emitió la Decisión IV/f sobre el cumplimiento por parte de España de las obligaciones del Convenio, en la cual se declaraba que aún no se habían adoptado todas las medidas necesarias para poner fin al incumplimiento de las diversas disposiciones del Convenio, entre ellas las relativas a la participación del público, y se reiteraba que era necesario "concienciar a las administraciones y a las personas al servicio de las mismas para establecer plazos de participación pública en los procesos de toma de decisiones de tal manera que se excluyan los

\footnotetext{
183 Vid. ECE, Findings and recommendations (2010), cit., p. 11.

184 UNECE, Report of the Compliance Committee on its Thirty-first meeting, "Compliance by Spain with its obligations under the Convention", Ginebra, 22-25 de febrero de 2011, ECE/MP.PP/C.1/2011/2/Add.7, p. 7 $<$ http://www.unece.org/env/pp/compliance/Compliancecommittee/36TableSpain.html> [última consulta, 28 de abril de 2018].
} 
periodos de vacaciones y se permita una amplia participación"185. La quinta reunión de las partes, celebrada en 2014, se pronunció de nuevo en la Decisión V/9k ${ }^{186}$, para finalmente declarar que España había puesto fin al incumplimiento de los párrafos 3 y 6 del artículo 6 en materia de participación pública en relación con los específicos incumplimientos constatados en los informes sobre las comunicaciones ACCC/C/2008/24 y ACCC/C/2009/36, si bien aún quedaba pendiente el cumplimiento de las recomendaciones relacionadas con las disposiciones sobre acceso a la información y de acceso a la justicia, que también se declararon vulneradas a raíz de dichas comunicaciones y que han sido objeto de seguimiento ulterior por el Comité187.

Esta recomendación en relación con los plazos tiene un importante impacto en la regulación y, fundamentalmente, en la aplicación de los plazos establecidos en la normativa estatal y autonómica, en donde, como hemos visto en relación con las disposiciones básicas examinadas en apartados precedentes, los plazos se cuentan frecuentemente por días naturales (habitualmente de treinta o cuarenta y cinco días) y, en ocasiones, por meses (generalmente un mes, y solo excepcionalmente se pueden encontrar plazos más amplios, como los de seis meses previstos en la planificación hidrológica). Ciertamente, en ocasiones esas disposiciones se limitan a fijar plazos mínimos, si bien permiten a las Administraciones modular en cada caso plazos más amplios ${ }^{188}$.Además, incluso cuando no se establecen con carácter mínimo, los plazos pueden ser ampliados de oficio o a petición de parte por la Administración competente si las circunstancias así lo aconsejan, aplicándose en caso de ausencia de previsión expresa en la normativa sectorial lo dispuesto en el artículo 32 LPCAP. Estas decisiones deberán ser

185 ECE, Decision V/9f on compliance by Spain with its obligations under the Convention, adoptada el 1 de julio de 2011 conforme al mandato establecido en el párrafo 37 del anexo de la Decisión 1/7 de la reunión de las partes sobre el seguimiento del cumplimiento (ECE/MP.PP/2011/CRP.8), apartado 6.

186 ECE, Decision V/9k on compliance by Spain, Maastricht, 30 de junio a 1 de julio de 2014, ECE/MP.PP/2014/2/Add.1, adoptada conforme al mandato establecido en el párrafo 35 del anexo de la Decisión $1 / 7$ de la reunión de las partes sobre el seguimiento del cumplimiento (ECE/MP.PP/2/Add.8), y al párrafo 19 de la decisión V/9 de la reunión de las partes (ECE/MP.PP/2014/2/Add.1), $<$ https://www.unece.org/fileadmin/DAM/env/pp/mop5/Documents/Post session docs/Decision excerpts in English/ Decision $\mathrm{V} 9 \mathrm{k}$ on compliance by Spain.pdf> [última consulta, 28 de abril de 2018].

${ }_{187}$ En cumplimiento de la Decisión, España envió informes de progreso periódicos al Comité (el 19 de diciembre de 2014, el 21 de octubre de 2015 y el 5 de diciembre de 2016) sobre las medidas adoptadas para poner fin a los incumplimientos. Finalmente, el Comité de Cumplimiento presentó en la sexta reunión de las partes (Budva, Montenegro, 11-13 de septiembre de 2017) un informe de cumplimiento en el que declaró que España todavía no había cumplido los requisitos del párrafo 6 de la Decisión V/9k, relativos a las disposiciones de los párrafos 4 y 5 del artículo 9, sobre acceso a la justicia y a la asistencia jurídica por parte de ONG. UNECE, Report of the Compliance Committee, Compliance by Spain with its obligations under the Convention, Montenegro 11-13 de septiembre de 2017, $\quad$ ECE/MP.PP/2017/43, $\quad$ p. $\quad 5$. $<$ https://www.unece.org/fileadmin/DAM/env/pp/mop6/English/ECE MP.PP 201743 E.pdf>, [última consulta, 28 de abril de 2018]. A raíz de este, la sexta reunión de las partes, celebrada en Budva del 11 al 13 de septiembre de 2017, adoptó la Decisión VI/8j (ECE/MP.PP/2017/2/Add.1), que declaraba dicho incumplimiento.

${ }^{188}$ En los casos en que no se establezca un plazo determinado, se aplicará lo dispuesto en la Ley 39/2015: en el trámite de consulta (art. 82.2), un mínimo de diez y un máximo de quince días, y en la información pública (art. 83.2), un mínimo de veinte días hábiles. 
adoptadas por la Administración competente atendiendo al volumen y la complejidad de la información que tenga que ser analizada por los ciudadanos para poder participar de forma efectiva. Por otro lado, siguiendo las recomendaciones del Comité de Cumplimiento y de la reunión de las partes, se deberá evitar situar los trámites de participación en períodos vacacionales (agosto, por ejemplo) y se deberá tener presente la concurrencia de días feriados en el caso de plazos que se computen por días naturales, problema que puede resolverse fácilmente si el legislador opta por plazos que se computen en días hábiles y establece en un calendario oficial los días $-\mathrm{y}$, en su caso, meses - inhábiles. En definitiva, de lege ferenda sería deseable que el legislador (básico y autonómico) tome en consideración las recomendaciones del Comité, a los efectos de valorar el establecimiento de plazos suficientemente amplios como para evitar incumplimientos de las disposiciones del Convenio por parte de aquellas Administraciones que puedan no ser especialmente receptivas a la ampliación de plazos o a su ubicación atendiendo a las consideraciones expuestas.

ii. La Comunicación ACCC/C/2014/99, de 20 de enero 2014, y las "limitaciones" de las comunicaciones a través de las nuevas tecnologías

El 20 de enero la organización ambiental Fons de Defensa Ambiental - FDA envió al Comité de Cumplimiento una comunicación en la que se denunciaba, entre otros, el incumplimiento del artículo 6, apartados 2, 3, 4, 8 y 9 ${ }^{189}$, por parte del Departamento de Medio Ambiente y Vivienda de la Generalitat de Catalunya, y se alegaba, en esencia, que se había impedido la participación temprana y efectiva del público en el procedimiento para otorgar una autorización solicitada por una cementera (Uniland Cementera, S. A.) que implicaba un cambio sustancial en su actividad.

La cementera había solicitado autorización para usar residuos sólidos urbanos y lodos de depuradora como combustible. Sin embargo, durante el trámite de información pública no se informó sobre dicho aspecto, sino sobre "un proyecto para producir cemento y extracción de roca". En su comunicación, el FDA argumentó que, siendo esto una modificación sustancial en la actividad de la planta cementera — conforme al artículo 4.1 de la Ley $3 / 1998$, de 27 de febrero, de la intervención integral de la Administración Ambiental, y al artículo 3.e) de la Ley 16/2002 IPPC—, dicha actividad necesitaba una nueva autorización. Se alegaba la vulneración del párrafo 2 del artículo 6 del Convenio por no informar al público de forma adecuada y eficaz

\footnotetext{
189 Dicha Comunicación está firmada, en su condición de secretario del FDA, por el profesor Alexandre Peñalver i Cabré, reconocido experto en derecho ambiental y, en particular, en materia de acceso a la justicia, participación pública y acceso a la justicia en materia de medio ambiente.
} 
cuando se inició el proceso de toma de decisiones, así como de los párrafos 3, 4 y 8 de dicho artículo, con lo que se había impedido la participación efectiva del público conforme a las exigencias de dichas disposiciones. Además, la Comunicación argumentaba que el público tampoco fue informado adecuadamente sobre la autorización finalmente otorgada, puesto que esta tan solo había sido publicada en internet, lo que vulneraba el párrafo 9 del artículo 6 del Convenio.

El Comité finalmente apreció que, en efecto, se había producido la vulneración del apartado 2 del artículo 6 del Convenio (información eficaz y temprana) ${ }^{190}$. Declaró, asimismo, la infracción del párrafo 9 del artículo 6 (información al público una vez adoptada la decisión siguiendo el procedimiento apropiado) porque el texto de la decisión finalmente adoptada por la Generalitat fue únicamente publicado en la web del Departamento de Medio Ambiente de la Generalitat. Tras poner de relieve que los Estados parte del Convenio gozan de cierta discrecionalidad para establecer cuál ha de ser el "procedimiento apropiado" para informar al público, invocando la "Recomendación de Maastricht sobre la promoción de una efectiva participación en la toma de decisiones ambientales"191, precisó que, cuando se comunique la resolución finalmente adoptada conforme al párrafo 9 , se deben utilizar los mismos métodos de comunicación con el público que los usados para informar al público interesado al comienzo de un proceso de toma de decisión conforme al párrafo 2. Sin embargo, en este caso no hubo tal consistencia entre los medios de comunicación utilizados al comienzo de la tramitación —que se llevó a cabo, además de a través de la página web, por otros medios- y la ulterior resolución ${ }^{192}$. Por otro lado, el Comité consideró que limitar la publicación exclusivamente a través de medios electrónicos puede excluir a ciertos miembros del público que no usan internet o no tienen acceso a ella, con lo que se les priva de la posibilidad de ser informados adecuadamente.

En este caso, el Comité ha recomendado al Estado que adopte las medidas legislativas, reglamentarias o de otro tipo para asegurar que el público sea informado rápidamente de la decisión finalmente adoptada no solo a través de internet, sino también de otros medios, incluyendo, pero no necesariamente solo, los utilizados para informar al público cuando se inicie un proceso de toma de decisiones conforme al párrafo 2 del artículo $6^{193}$. Tal incumplimiento fue

\footnotetext{
190 Descartó, sin embargo, la de los párrafos 3, 4 y 8, puesto que la comunicación no identificó de forma precisa las vulneraciones, argumentando que todas las alegaciones al respecto conducían a apreciar la vulneración del apartado 2 del artículo 6.

191 UNECE, Maastricht Recommendations on Promoting Effective... cit.

192 UNECE, Compliance Committee, Findings and recommendations with regard to communication ACCC/C/2014/99 concerning compliance by Spain, ECE/MP.PP/C.1/2017/17, p. 17.

193 Ibid.
} 
también constatado por la sexta reunión de las partes, celebrada en 2017, mediante su Decisión $\mathrm{VI} / 8 \mathrm{8j} 194^{195}$.

iii. La Comunicación ACCC/C/2014/122, de 12 de diciembre 2014: ¿una "vulneración masiva" de la normativa IPPC?

En su Comunicación de 12 de diciembre de 2014, el Instituto Internacional del Medio Ambiente (IIMA) denunció una vulneración masiva del artículo 6.10 del Convenio a raíz de la disposición transitoria primera introducida en la Ley 16/2002 IPPC por la Ley 5/2013, que la modifica con el objeto de adecuarla a la Directiva 2010/75/UE del Parlamento Europeo y del Consejo, de 24 de noviembre de 2010, sobre las emisiones industriales.

En dicha modificación, y como medida de simplificación administrativa, se suprimió el deber de renovación de dicha autorización y se estableció un procedimiento simplificado en virtud del cual el órgano ambiental competente debía comprobar, de oficio y mediante un procedimiento simplificado, la adecuación de la autorización a las prescripciones de la nueva Directiva. La fecha límite para la actualización de las autorizaciones era el 7 de enero de 2014.

EI IIMA argumenta en su Comunicación que tal procedimiento de oficio prescinde de cualquier trámite de participación pública, lo que vulnera el apartado 10 del artículo 6.10 del Convenio. Dicho apartado establece lo siguiente: "Cada Parte velará porque, cuando una autoridad pública reexamine o actualice las condiciones en que se ejerce una actividad mencionada en el apartado 1, las disposiciones de los apartados 2 a 9 del presente artículo se apliquen mutatis mutandis y como corresponda".

En el momento de cerrar este trabajo, el Comité sigue examinando las alegaciones de las partes. La respuesta del Gobierno español a la Comunicación argumenta, fundamentalmente, que la disposición transitoria primera se adopta para adecuar el ordenamiento interno a la Directiva 2010/75/UE y que su contenido está determinado por la distinción que dicha Directiva establece entre "revisión" de las condiciones del permiso y "actualización" para adecuarlas a las disposiciones de la nueva Directiva, actualización para la que se establece un plazo de cuatro

\footnotetext{
194 UNECE, Decision VI/8j Compliance by Spain with its obligations under the Convention, Excerpt from the addendum to the report of the sixth session of the Meeting of the Parties (ECE/MP.PP/2017/2/Add.1), Montenegro, 11-13 de septiembre, disponible en $<$ www.unece.org/fileadmin/DAM/env/pp/compliance/MoP6decisions/Compliance by Spain VI-8j.pdf> [última consulta, 28 de abril de 2017].

195 UNECE, Decision VI/8j... cit., apartados 5 y 6.
} 
años $^{196}$. Por el contrario, la revisión — que es lo que entiende la Administración que queda sujeto a lo dispuesto en el apartado 9 del artículo 6- tiene lugar cuando las particularidades de la instalación cambian, por ejemplo, por una extensión de su capacidad o porque entra en vigor una nueva norma sobre las mejores tecnologías disponibles (BAT). Además, a diferencia del procedimiento de revisión, el de actualización no está incluido entre aquellos que, conforme al artículo 24 de la Directiva, requieren la participación del público.

A la luz de la redacción del apartado 10 del artículo 6 del Convenio, podríamos estar no tanto ante un conflicto entre esta disposición del Convenio y el artículo 24 de la Directiva ${ }^{197}$, sino más bien ante una laguna de esta última, al no prever la participación pública en el proceso de actualización. Si finalmente el Comité entiende que los conceptos "actualizar" y "reexaminar" del apartado $10 \mathrm{del}$ artículo 6 del Convenio son equivalentes - lo que no es en absoluto improbable-, la conclusión a la que puede llegar es que se debería haber garantizado la aplicación de todas las obligaciones establecidas en el artículo 6 sobre participación pública en el proceso de actualización contemplado en la disposición transitoria primera introducida por la Ley 5/2013. De ser esto así, la laguna del artículo 24 de la Directiva no excusaría, en absoluto, el incumplimiento del Convenio por parte de los Estados.

\section{CONSIDERACIONES FINALES}

A la luz del examen de las normas sobre participación pública que hemos expuesto, se puede concluir que -en términos generales y con las salvedades indicadas- el ordenamiento español responde formalmente a lo dispuesto en el segundo pilar del Convenio de Aarhus. Es más, gracias al Convenio y a las directivas de la UE, las normas sobre participación en materia de medio ambiente se han desarrollado con un grado de precisión y de exigencia notablemente superior al de otros ámbitos de actividad administrativa ${ }^{198}$.

\footnotetext{
196 Art. 21.

197 Conflicto que, si no pudiera resolverse por la vía de la interpretación conforme del derecho de la Unión con el Convenio, según la jurisprudencia del Tribunal de Justicia de la Unión Europea, deberá resolverse a favor de este último, dado que los acuerdos celebrados por la Unión con terceros Estados y organizaciones internacionales son vinculantes tanto para sus instituciones como para los Estados miembros, priman sobre el derecho derivado y son parámetro para su interpretación (vid., entre otros, los asuntos 21-24/72, International Fruit Company, de 12.12.1972). En cuanto al deber de interpretar, en la medida de lo posible, los textos del derecho comunitario a la luz del derecho internacional -en particular, cuando dichos textos tienen por objeto precisamente la aplicación de un acuerdo internacional firmado por la Unión_, vid., entre otros, el as. C-284/95, Safety Hi-Tech de14.7.1998.

198 Más intenso y visible incluso, como ha reconocido el Tribunal Supremo, que en el ámbito del urbanismo; vid. STS núm. 1188/2017, Sala 3. ${ }^{a}$ de lo Contencioso-Administrativo, de 7 de julio de 2017 (recurso 1783/2017), FJ 5. ${ }^{\circ}$.
} 
Siendo imprescindible contar con un marco normativo adecuado, es obvio que por sí solo no basta para lograr una participación ciudadana "real y efectiva". Los propios informes de cumplimiento presentados por España a las reuniones de las partes ponen de manifiesto que la participación pública en estos procedimientos sigue siendo muy "escasa". Es necesario, por lo tanto, impulsar una actitud proactiva desde la Administración y explorar distintas posibilidades y opciones, más allá de los trámites mínimos establecidos por la normativa, que promuevan y mejoren la calidad de la participación. Para ello sigue siendo precisa la adecuada formación y sensibilización del personal al servicio de las distintas Administraciones en relación con las obligaciones que les impone el Convenio de Aarhus en materia de participación, en particular, en los entes locales.

Igualmente importante es el uso de medios de comunicación adecuados que permitan una información temprana sobre el contenido de los procesos de autorización, planificación o programación que vayan a ponerse en marcha, y el recurso a instrumentos tales como encuestas, seminarios y audiencias o conferencias públicas, antes incluso de que se abran los plazos formales de información y consulta pública, que refuercen el conocimiento sobre la decisión o plan en cuestión, y, como consecuencia, aumente la capacidad y el interés de la ciudadanía por participar en la adopción de la decisión a través de los cauces finalmente habilitados. Junto a la publicidad a través de diarios oficiales y notificaciones de la apertura de procesos de información y consulta, se están utilizando las nuevas tecnologías de información y comunicación para darles mayor difusión y poner a disposición del público la documentación pertinente (a través de páginas web oficiales y, en su caso, de las redes sociales). Pero no se puede obviar la importancia que también tienen otros medios tradicionales (comunicados de prensa, radio y otros medios de comunicación convencionales) que permiten una amplia difusión y llegar al conjunto de la población, incluyendo a las personas a las que la brecha digital haya podido dejar al margen del uso de las nuevas tecnologías. La calidad y la forma de presentar la información al público y los medios utilizados a tal efecto determinan, en definitiva, la capacidad de participación del público en general y de las personas interesadas en particular.

Otro reto pendiente es articular formas flexibles de participación que, al mismo tiempo, no generen retrasos o dificultades excesivas o injustificadas en la actuación administrativa para adoptar las soluciones más aceptables para la mayoría de los intereses afectados (sociales, económicos y ambientales). Para ello es preciso encontrar el equilibrio entre participación efectiva y eficacia de la acción administrativa, buscando las sinergias entre ambas para mejorar los procesos de toma de decisión administrativa y evitar que puedan percibirse como principios 
antagónicos en el procedimiento. Entre otros, el tema de los plazos juega aquí un papel clave. La escasez de los plazos de participación es, como se ha puesto de relieve en los apartados precedentes, una de las críticas recurrentes en la aplicación de la normativa examinada (particularmente cuando se fijan plazos de días o de un mes). La calificación de un plazo como "razonable" va a depender generalmente de la complejidad del proyecto, plan o programa, y de si se ha puesto a disposición del público con antelación suficiente información adecuada para que, si fuera necesario, quien lo estime oportuno recabe opinión o informes de expertos para valorar cuestiones altamente técnicas, así como para definir con suficiente conocimiento las alegaciones que estime pertinentes. Las decisiones del Comité de Cumplimiento han puesto de relieve, por otro lado, la insuficiencia de algunos plazos fijados en la normativa estatal o autonómica por días, como en el caso de autorización de proyectos o aprobación de planes y programas complejos. Insuficiencia que se puede ver agravada, además, cuando no se ha facilitado de forma adecuada la información y/o cuando el período establecido para acceder a esta y presentar alegaciones se ve reducido de facto por coincidir con períodos vacacionales o días feriados.

Resulta igualmente fundamental avanzar hacia una participación que los ciudadanos puedan percibir como un diálogo en el que sus aportaciones son analizadasa en todo momento por la Administración y en el que se les informa adecuadamente sobre en qué medida se han tenido en cuenta las alegaciones realizadas y del impacto que tiene el proceso de participación en las decisiones que finalmente adopten las autoridades públicas. Para generar una cultura de participación es necesario, en definitiva, evitar la percepción de que tales mecanismos son un mero trámite o un diálogo de sordos, de forma que las personas u organizaciones que decidan participar en el proceso de toma de decisión de la Administración tengan un retorno adecuado sobre en qué medida sus aportaciones han podido ser aceptadas en la decisión final o se les comunique de forma motivada la razón por la que estas han sido desestimadas.

Por último, es preciso que los incumplimientos en que, en su caso, incurran las Administraciones puedan ser objeto de recursos accesibles y eficaces ante los tribunales, como exige el propio Convenio en su tercer pilar.

Por otro lado, más allá de las normas y de cómo sean aplicadas por la Administración y los tribunales, y de los mecanismos de control establecidos por el propio Convenio de Aarhus, para que la participación redunde en una mejor protección del medio ambiente son presupuestos necesarios la concienciación, la sensibilización y la implicación de los ciudadanos en un modelo 
de desarrollo sostenible; en definitiva, la cultura de una sociedad educada en el respeto del medio ambiente, aspecto este que también tienen que liderar los poderes públicos.

En España, tanto el legislador como las Administraciones y los tribunales han hecho, sin duda, un notable esfuerzo para dar cumplimiento a las disposiciones del Convenio de Aarhus en los últimos años. Pero aún queda mucho por hacer para alcanzar una participación pública que permita perfilar en cada caso, de la forma más acertada posible, los contornos de los intereses colectivos vinculados al medio ambiente y del interés general de toda la sociedad en la protección y mejora del medio ambiente.

Solo si se conoce y reconoce la utilidad real de la participación pública por todos los agentes implicados podrá alcanzarse este objetivo. Ese es el gran reto de la participación pública en materia de medio ambiente en España, al que la sociedad en su conjunto, con el decidido compromiso de los poderes públicos, tiene que dar respuesta.

\section{BIBLIOGRAFÍA}

ALENZA GARCÍA, J. F., "La participación en la planificación de residuos", Revista Aranzadi de Derecho Ambiental, núm. 36, enero-abril 2017, pp. 21-35.

ALONSO GARCÍA, E., "La participación de individuos en la toma de decisiones relativas al medio ambiente en España", Revista española de derecho administrativo, núm. 61, 1989, pp. 49-66.

ARAGUÀS GALCERÀ, I., "La participación ciudadana en la elaboración de disposiciones generales: estado de la cuestión y perspectivas de futuro tras la aprobación de la Ley 39/2015, de 1 de octubre, de Procedimiento Administrativo Común de las administraciones públicas", Revista Andaluza de Administración Pública, núm. 96, 2016, pp. 85-126.

- "La nulidad de los reglamentos por defectos en la realización de los trámites participativos", Actas del XII Congreso de la Asociación Española de Profesores de Derecho Administrativo, 2017, pp. 487-498.

BERMEJO LATRE, J. L., "La participación del público en la protección de la biodiversidad", Monografías de la Revista Aragonesa de Administración Pública, núm. 16, 2016, pp. 151-176.

CUBERO MARCOS, J. L., ITURRIBARRIA RUIZ, M. y LASAGABASTER HERRARTE, I., Acceso a la información, participación y acceso a la justicia en materia de medio ambiente, Gobierno Vasco, 2009.

- "Proyectos y planes aprobados por Ley: contradicción a la luz de la evaluación ambiental, el derecho de participación y acceso a la justicia en materia ambiental", RVAP, núm. 99-100, 2014, pp. 1007-1039.

EMBID IRUJO, A., "Valoración global del nuevo ciclo de la planificación hidrológica, con atención especial al Plan Hidrológico de la parte española de la demarcación hidrográfica del Ebro", Embid Irujo, A. (dir.), El segundo ciclo de planificación hidrológica en España (20102014), Thomson-Aranzadi, Madrid, 2015. 
ESPLUGA, J., BALLESTER, A., HERNÁNDEZ-MORA, N. y SUBIRATS, J., "Participación pública e inercia institucional en la gestión del agua en España", núm. 134, 2011, Revista Española de Investigaciones Sociológicas, pp. 3-26.

FERNÁNDEZ RODRÍGUEZ, T. R., "Derecho, Medio Ambiente, y Desarrollo”, REDA, núm. 24, 1980, pp. 5-16.

GARCÍA-ÁLVAREZ GARCÍA, G., "Acceso a la información, participación pública y acceso a la justicia en cuestiones ambientales: del Convenio de Aarhus a la Sentencia Boxus", Revista Aragonesa de Administración Pública, XIV, 2013, pp. 433-472.

GARCÍA URETA, A., "Algunas cuestiones sobre la regulación del derecho de participación a la luz del Convenio de Aarhus de 1998", Revista Aranzadi de Derecho Ambiental, 7/2005, pp. 4370.

- "Convenio de Aarhus y convalidaciones legislativas: ¿Recurso directo contra leyes en vía contenciosa? Comentario a la sentencia del TJUE (Gran Sala) de 18 de octubre de 2011, Boxus v. Regione Wallone, asuntos acumulados C-128/09 a C-131/09, C134/09 y C-135/09", Diario La Ley, núm. 7763, Sección Doctrina, 27 de diciembre de 2011, año XXXII, ref. D-482.

- "Comentarios sobre la Ley 21/2013 de Evaluación Ambiental", RAP, núm. 194, 2014, 317-371.

GONZÁLEZ BONDÍA, A., "La regulación comunitaria del acceso a la información, la participación pública y el acceso a la justicia en materia de medio ambiente en sus Estados miembros", Pigrau i Solé, A. (dir.), Acceso a la información, participación pública y acceso a la justicia en materia de medio ambiente: diez años del convenio de Aarhus, Atelier, Barcelona, 2008, pp. 97-107.

GARCÍA GARCÍA, M. J., "La participación ciudadana en la elaboración de disposiciones reglamentarias: participación funcional e iniciativa reglamentaria", Revista catalana de dret públic, núm. 37, 2008, pp. 417-460.

JARIA I MANZANO, J., "La participación del público en la evaluación ambiental estratégica", Revista Aranzadi de Derecho Ambiental, núm. 11, 2007, pp. 213-222.

- "El fundamento constitucional de los derechos de participación en materia de medio ambiente y su desarrollo en la Ley 27/2006", Pigrau i Solé, A. (dir.), Acceso a la información, participación pública y acceso a la justicia en materia de medio ambiente: diez años del convenio de Aarhus, Atelier, Barcelona, 2008, pp. 119-148.

JORDANO FRAGA, J., "Derecho a la participación, participación administrativa y medio ambiente", Revista Andaluza de Administración Pública, núm. 11, 1992, pp. 99-110.

LASAGABASTER HERRARTE, I., "Participación y protección del medio ambiente", García Ureta, A. (coord.), Estudios de Derecho ambiental europeo, Lete, Bilbao, 2005, pp. 13-44.

LEMA BLANCO, I. y GARCÍA MIRA, R., "Participación Pública en la Gestión del Agua. Un análisis de los procesos participativos desarrollados sobre los planes hidrológicos de las cuencas gallegas", Administración \& Ciudadanía, vol. 8, núm. 2, 2013, pp. 9-24.

LÓPEZ RAMÓN, F., "Introducción general: perplejidades en el años de Fukushima”, AA. VV., Observatorio de Políticas Ambientales 2012, Thomson-Aranzadi, Cizur Menor, 2012, pp. 43-46.

LOZANO CUTANDA, B., "Análisis general de la Ley 27/2006 de acceso a la información, participación pública y acceso a la justicia en materia de medio ambiente", Lozano Cutanda, B. (dir.), Examen de la nueva Ley de acceso a la información, participación pública y acceso a la justicia en materia de medioambiente, Estudios de Derecho Judicial, núm. 137, 2007, pp. 169206. 
MARTÍNEZ OROZCO, M., "El modelo español de participación pública en la evaluación de impacto ambiental: el largo camino hacia Aarhus", Evaluación de impacto ambiental en España: nuevas perspectivas - Actas del IV Congreso Nacional de Evaluación de Impacto Ambiental, IV CONEIA, Madrid, 2008.

NOGUEIRA LÓPEZ, A., "La participación en la evaluación de impacto ambiental. Dogma y realidad", García Ureta, A. (coord.), La Directiva de la Unión Europea de evaluación de impacto ambiental de proyectos: balance de treinta años, Marcial Pons, Madrid, 2016, pp. 117-156.

- “¿Participación efectiva o quimera procedimental?”, NOGUEIRA LÓPEZ, A. (dir.), Evaluación de impacto ambiental: evolución normativo-jurisprudencial, cuestiones procedimentales $y$ aplicación sectorial, Atelier, Barcelona, pp. 121-145.

PALLARÉS SERRANO, A., "La participación pública en materia de medio ambiente", Pigrau i Solé, A. (dir.), Acceso a la información, participación pública y acceso a la justicia en materia de medio ambiente: diez años del convenio de Aarhus, Atelier, Barcelona, 2008, pp. 299-348.

PEÑALVER I CABRÉ, A., "Nuevos instrumentos para la aplicación de la legislación ambiental ante la inactividad administrativa: de las acciones ciudadanas (citizen suits) al Convenio de Aarhus", Revista de Administración Pública, 172, 2007, pp. 474-475.

- La defensa de los intereses colectivos en el contencioso-administrativo, Thomson-Aranzadi, Cizur Menor, 2016.

PIGRAU SOLÉ, A. (dir.), Acceso a la información, participación pública y acceso a la justicia en materia de medio ambiente: diez años del convenio de Aarhus, Atelier, Barcelona, 2008.

PIGRAU SOLÉ, A. y BORRÁS PENTINAT, S., "Diez años del Convenio de Aarhus sobre el acceso a la información, la participación y el acceso a la justicia en materia de medio ambiente", Pigrau i Solé, A. (dir.), Acceso a la información, participación pública y acceso a la justicia en materia de medio ambiente: diez años del convenio de Aarhus, Atelier, Barcelona, 2008, pp. 2180.

PLAZA MARTÍN, C., Derecho Ambiental de la Unión Europea, Tirant lo Blanch, Valencia, 2005.

RAZQUIN LIZARRAGA, J. A. y RUIZ DE APODACA ESPINOSA, A., Información, participación y justicia en materia de medio ambiente. Comentario sistemático a la Ley 27/2006, de 18 de julio, Thomson-Aranzadi, Cizur Menor, 2007.

RAZQUIN LIZARRAGA, M. M., "La evaluación ambiental: Tipos, Ámbito de Aplicación e Interrelación", Ruiz de Apodaca Espinosa, A. (dir.), Régimen Jurídico de la Evaluación Ambiental, Comentario a la Ley 21/2013, de 9 de diciembre, de evaluación ambiental, Thomson Reuters, Cizur Menor, 2014, pp. 117-211.

RUIZ DE APODACA ESPINOSA, A., "La participación orgánica en materia ambiental: el Consejo Asesor de Medio Ambiente y los consejos asesores de las Comunidades Autónomas", Revista Jurídica de Navarra, núm. 42, 2006, pp. 93-118.

RUIZ DE APODACA ESPINOSA, A., "El acceso a la justicia ambiental a nivel comunitario y en España veinte años después del Convenio de Aarhus”, Revista Catalana de Dret Ambiental, Vol. IX, Núm. 1, Junio, 2018.

SANTAMARÍA ARINAS, R. J., "Leyes singulares, tutela judicial efectiva y recepción de la doctrina 'Boxus' por el Tribunal Constitucional español”, RAP, núm. 193, 2014, pp. 165-195.

VICENTE DÁVILA, F., "30 años de aplicación de la evaluación ambiental: la participación pública efectiva, una asignatura pendiente", Revista Aranzadi de Derecho Ambiental, núm. 34, mayo-agosto 2016, pp. 217-231. 